\title{
The effect of low-temperature blanching on the quality of fresh and
} frozen/thawed mashed potatoes

\author{
Cristina Fernández, ${ }^{1}$ M. Dolores Alvarez ${ }^{1 *}$ \& Wenceslao Canet $^{1}$
}

1 Department of Plant Foods Science and Technology, Instituto del Frío-CSIC, José de Novaís nº 10, E-28040 Madrid, Spain

Running title

LTB effect on quality of mashed potatoes $C$. Fernández et al.

*Correspondent: Fax: +34 9154936 27;

e-mail: ifrat44@if.csic.es 
Summary The effect of low-temperature blanching (LTB) prior to cooking on colour, textural, firmness and oscillatory parameters, sensory attributes and overall acceptability of either fresh or frozen/thawed mashed potatoes was studied using Response Surface Methodology (RSM) to establish the optimum temperature and time for blanching in both types of mashed potatoes. A central composite rotatable design was used to study the effects of variation in levels of blanching temperature $\left(57.93-72.07^{\circ} \mathrm{C}\right)$ and time $(15.86-44.14 \mathrm{~min})$ on the quality parameters. Stationary points showing maximum thickening had critical temperatures (approximately $67-69{ }^{\circ} \mathrm{C}$ ) and times (approximately 26-30 $\mathrm{min}$ ) in the ranges of temperature and time used for each independent variable for both fresh and frozen/thawed mashed potato. Results showed a high correlation between structural reinforcement and overall acceptability under optimum experimental blanching conditions. This demonstrates the potential of this experimental approach in terms of tailoring physical properties to predetermined levels in order to meet consumer preferences in mashed potatoes, and of altering the changes that occur after freezing and thawing.

Keywords Preheating, potato puree, freezing, thawing, overall acceptability, response surface methodology, cryoprotectants, pectin methylesterase enzyme. 


\section{Introduction}

In the catering industry, mashed potato is prepared either directly from potatoes or by reconstituting dehydrated potato granules and flakes. The two major factors that determine a caterer's choice of mashed potato are cost and consumer preference. Consumer preference is influenced by a combination of flavour, texture and appearance (Canet et al., 2005a). Novais et al (1982) reported that flavour and texture contributed significantly to overall preference (64-68 and 32-36 per cent, respectively) of five mashed potato products.

Pre-treatments can have a great effect, particularly on the texture of the final potato product. The Add-Back process used in the manufacture of dehydrated instant mashed potato granules includes an essential pre-preparation stage consisting of precooking the potato at $70{ }^{\circ} \mathrm{C}$ for 20 min and cooling in water prior to steam cooking (Moledina et al., 1978). This serves to render the cell wall less degradable by cooking (Bartolome \& Hoff, 1972), thereby enabling the potato cells to withstand the forces generated by compression, mixing and rubbing during the continuous mash-mixing stage. Another technique, a low-temperature blanching (LTB) process has been reported by numerous authors, offering a promising approach to increasing firmness retention in processed potato. The literature gives different optimum blanching conditions for different potatoprocessing operations. Brown \& Morales (1970), recommended $80{ }^{\circ} \mathrm{C}$ for 15 min for lowtemperature blanching followed by $95{ }^{\circ} \mathrm{C}$ for $1 \mathrm{~min}$ for the blanching of potatoes prior to frying. Canet et al. (1982) compared blanching at $100{ }^{\circ} \mathrm{C}$ for 2 min of cylindrical potato specimens with both one-step blanching at $80{ }^{\circ} \mathrm{C}$ for $6 \mathrm{~min}$ and stepwise blanching at $50,60,70{ }^{\circ} \mathrm{C}$ for $10 \mathrm{~min}$, followed by cooling and a second step at $100{ }^{\circ} \mathrm{C}$ for 2 min; they concluded that LTB at 60 and $70{ }^{\circ} \mathrm{C}$ for 10 min clearly improved the texture of frozen potatoes when cooked. It has recently been shown 
that LTB of potatoes (cv. Kennebec), both without further processing and prior to cooking or freezing and cooking, significantly increased firmness retention as measured from compression parameters, demonstrating a high correlation between pectin methylesterase (PME) activity and tissue firmness (Canet et al., 2005b).

The effect of freezing temperature $\left(-80,-40,-24{ }^{\circ} \mathrm{C}\right)$ and thawing mode (microwave, overnight at $4{ }^{\circ} \mathrm{C}$ ) on quality parameters of mashed potato made from tubers (cv. Kennebec) and potato flakes was examined by Alvarez et al. (2005). In freshly-made mashed potato, processing resulted in a softer product than the fresh control according to texture profile analysis (TPA) hardness and oscillatory parameters. In the same way, freezing reduced the storage modulus $\left(\mathrm{G}^{\prime}\right)$, loss modulus (G”) and complex viscosity $\left(\eta^{*}\right)$ values of mashed potatoes made from dehydrated flakes, measured at $20{ }^{\circ} \mathrm{C}$, compared with freshly-made product. At this temperature, mashed potatoes made from frozen/thawed flakes consisted of dilute dispersions of swollen and disrupted intracellular starch granules (Alvarez \& Canet, 1999a). Changes in the viscoelastic properties of fruit and vegetable purees that have undergone freezing or freeze-thaw treatments are of practical significance for acceptance and consumption. One way of minimising damage from freezing and thawing is to incorporate cryoprotectants to alter crystal shapes. Recent studies have described the effect of individual and mixed hydrocolloids on the quality of frozen and thawed cooked potato purées (Downey, 2002, 2003).

Previous studies have shown that of various different potato varieties, Kennebec was the most suitable for producing fresh mashed potatoes of consistent quality (Alvarez et al., 2004; Canet et al., 2005a), and that freezing and thawing processes reduced most of the quality parameters measured in the product. However, LTB of potatoes (cv. Kennebec) prior to freezing and cooking significantly increased firmness retention (Canet et al., 2005b). The next step, and hence the 
purpose of the present research, was to investigate how mashed potato quality is affected by lowtemperature blanching (LTB) applied prior to cooking without further processing, and prior to cooking, followed by the freezing and thawing of the samples. A second objective, based on the results, was, using response surface methodology (RSM), to find the optimum blanching temperature and time to improve the quality and overall acceptability of fresh and frozen-andthawed mashed potato.

\section{Material and methods}

\section{Test material}

Data presented in this report were obtained using potato tubers (Solanum tuberosum, L., cv. Kennebec) from Galicia (Spain). The material was stored in a chamber at $4{ }^{\circ} \mathrm{C}$ and $85 \%$ relative humidity (Smith, 1987).

\section{Low-temperature blanching (LTB)}

Tubers were washed and peeled manually. Cylindrical specimens $12 \mathrm{~mm}$ in diameter and $10 \mathrm{~mm}$ in height were cut from potato tubers using a stainless-steel cork borer and a mechanically guided razor blade specially designed for this diameter (Gil, 1991). Cylindrical specimens were extracted from the central region of each tuber approximately $10 \mathrm{~mm}$ below the skin of each slice to avoid the large differences in texture reported to exist between the cortex and pith tissues due to the different size and shape of the cells (Anzaldúa-Morales et al., 1992). Blanching was carried out at 
the different combinations of temperature and time given by a central composite rotatable design (Table 1), with blanching temperature ranging between 60 and $70{ }^{\circ} \mathrm{C}$ and blanching time ranging between 20 and $40 \mathrm{~min}$, by placing the potato cylinders in a Hetofrig CB60VS (Heto Lab Equipment $\mathrm{A} / \mathrm{S}$, Birker $\varnothing \mathrm{d}$, Denmark) waterbath $\left(-30\right.$ to $\left.+110{ }^{\circ} \mathrm{C}\right)$ with a constant product weight:water volume ratio of 1:20. Water and specimen temperatures were monitored by T-type thermocouples $\left(\mathrm{NiCr} / \mathrm{NiAl} ;-200{ }^{\circ} \mathrm{C}\right.$ to $\left.+1000{ }^{\circ} \mathrm{C}\right)$ using a hardware and software system developed with the LabWindows/CVI package (National Instruments Spain S.L., Madrid, Spain) for automation of the thermal process control (Rico et al., 1995). After blanching, specimens were cooled in cold water for $10 \mathrm{~min}$.

\section{Preparation of mashed potatoes}

After blanching, mashed potatoes were prepared in 650-g batches from $395 \mathrm{~g}$ of cylindrical potato specimens, $150 \mathrm{~mL}$ of milk, $100 \mathrm{~mL}$ of water and $5 \mathrm{~g}$ salt using a thermal mixer TM 21 (Vorwerk España M.S.L., S.C., Madrid, Spain). The ingredients were cooked for 20 min at 100 ${ }^{\circ} \mathrm{C}$ (blade speed: $100 \mathrm{rpm}$ ), and the amount of liquid evaporated during boiling was determined by weighing the ingredients before and after boiling. The evaporated liquid was then replaced by to an equal weight of boiling water, and the ingredients were again cooked at $100{ }^{\circ} \mathrm{C}$ for 5 min. The mash was immediately ground for $40 \mathrm{~s}$ (blade speed: $2000 \mathrm{rpm}$ ). The product was immediately homogenised through a stainless steel sieve (diameter $1.5 \mathrm{~mm}$ ). In this study, two samples of mashed potato were used as controls. The first control was prepared directly as indicated above but without prior blanching. The second control was likewise prepared without blanching, but in this case modified waxy cornstarch C*Polar Tex 06716 (high amylopectin, 
cross-linked, di-starch phosphate) (Cerestar Ibérica, S.L.), was diluted in the $250 \mathrm{~mL}$ of water and milk and added to the rest of the ingredients before cooking. Range finding experiments were performed to ascertain the maximum acceptable amount of starch that could be added to the mashed potato without appreciable sensory changes in colour and taste. On this basis, the maximum acceptable level of starch use was established at $0.5 \%(\mathrm{w} / \mathrm{w})$.

Following preparation, half of each mashed potato sample was immediately analysed and the other half was packed in polyethylene plastic, sealed under light vacuum $(-0.05 \mathrm{MPa})$ on a Multivac packing machine (Sepp Haggenmüller KG, Wolfertschwenden, Germany), and frozen and thawed according to the freezing and thawing procedures indicated below. Large thin packs were made so as to minimise the differences in freezing and thawing rates between mashed potato at the surface and deep within the pack.

\section{Freezing and thawing procedures}

Mashed potato was frozen by forced convection with liquid nitrogen vapour in an Instron programmable chamber (model $3119-05,-70^{\circ} \mathrm{C} /+250^{\circ} \mathrm{C}$ ) at $-60{ }^{\circ} \mathrm{C}$ until their thermal centres reached $-24{ }^{\circ} \mathrm{C}$ (Alvarez et al., 1997). Air and product temperatures were monitored by T-type thermocouples $\left(\mathrm{NiCr} / \mathrm{NiAl} ;-200\right.$ to $\left.+1000{ }^{\circ} \mathrm{C}\right)$ using the $\mathrm{MMS} 3000^{\mathrm{TM}}$ Multi Measurement System $^{\mathrm{TM}}$ (Mod. T4, Commtest Instruments, New Zealand). The software permitted real-time data gathering and storage and also the calculation of the freezing rate $\left(-2 \pm 0.10{ }^{\circ} \mathrm{C} \mathrm{min}{ }^{-1}\right)$. After freezing, the samples were placed in a domestic freezer for storage at $-24{ }^{\circ} \mathrm{C}$ and left there for $7 \mathrm{~d}$ before thawing. For the microwave thawing process, the frozen mashed samples were unpacked, immediately placed in flat microwave trays and then thawed in a Samsung M1712N (Samsung 
Electronics S.A., Madrid, Spain) microwave oven. In all cases the samples were placed in the same position and irradiated for a total of 20 minutes with output power ratings of $600 \mathrm{~W}$. The power setting was $100 \%$. Thawing was conducted in two steps. Initially, the samples were irradiated for 15 minutes, then removed from the microwave and stirred gently (shear rate $\approx 10 \mathrm{~s}^{-}$

${ }^{1}$ ) with a spoon for $1 \mathrm{~min}$ to equilibrate the sample temperature. Next, the samples were placed in the microwave again and irradiated for an additional 5 min under the same conditions. After this procedure, the temperature reached by the thermal centre of the product was measured in all cases $\left(+50 \pm 5^{\circ} \mathrm{C}\right)($ Alvarez et al., 2005).

\section{Heating of samples}

All the fresh and frozen/thawed samples were allowed to reach $55^{\circ} \mathrm{C}$ by placing them in the Hetofrig CB60VS (Heto Lab Equipment A/S, Birkerød, Denmark) waterbath, where again water and product temperatures were monitored by T-type thermocouples using the hardware and software system described above (Rico et al., 1995). The selected sample testing temperature was $55{ }^{\circ} \mathrm{C}$, since results from different analyses showed that this is the preferred temperature for consumption of mashed potato (Alvarez et al., 2004; Canet et al., 2005a).

\section{Colour}

The colour of the mashed potato samples in the pots was measured using a HunterLab model D25 (Reston, Virginia, USA) colour difference meter fitted with a $5 \mathrm{~cm}$ diameter aperture fitted with a $5 \mathrm{~cm}$ diameter aperture. Measurements were performed in triplicate and the results averaged. 
Results were expressed in $\mathrm{L}^{*} \mathrm{a}^{*} \mathrm{~b}^{*}$ scale, where $\mathrm{L}^{*}$ indicates the lightness, $\mathrm{a}^{*}$ represents the green-red colour axis and $\mathrm{b}^{*}$ the blue-yellow axis, recommended by the International Commission on Illumination (CIE, 1978). Colour was also expressed as $\mathrm{L}^{*} / \mathrm{b}^{*}$, i.e. the white/yellow ratio (O’Leary et al., 2000; Redmond et al., 2002).

\section{Dry matter}

Determinations were made by drying in an oven at $75^{\circ} \mathrm{C}$ for $18 \mathrm{~h}$. Samples were weighed using a Mettler AJ 100 (Mettler Instruments AG, Zurich, Switzerland) analytical scales, accurate to $0.00001 \mathrm{~g}$. The initial weight of each sample was approximately $10 \mathrm{~g}$. Measurements were performed in triplicate and the results averaged.

\section{Instrumental objective texture measurements}

Texture profile analysis and firmness tests were carried out with a TA.HDi Texture Analyser (Stable Micro Systems Ltd, Godalming, UK) using a $250 \mathrm{~N}$ load cell and the application program provided with the apparatus (Texture Expert for Windows ${ }^{\mathrm{TM}}$, version 2. 61). During the tests, the mashed potato samples were maintained at $55^{\circ} \mathrm{C}$ by means of a Temperature Controlled Peltier Cabinet (XT/PC) coupled to a separate heat exchanger and PID control unit (Canet et al., 2005a). For TPA tests, a flat 35-mm diameter aluminium plunger (SMS P/35) was used to move within a 60-mm diameter stainless steel cylinder containing $50 \pm 1 \mathrm{~g}$ of mashed potatoes. The Texture Analyser was programmed so that the downward movement began at a point $8 \mathrm{~mm}$ above the surface of the sample. The following experimental conditions were selected for each TPA test: 
deformation rate $\left(180 \mathrm{~mm} \mathrm{~min}^{-1}\right)$, compression level $(33.3 \%)$, with a rest period of $5 \mathrm{~s}$ between cycles. There were four replicates for each experimental unit. The program software (Texture Expert for Windows, version 1.0; Stable Micro Systems, Surrey, England) automatically calculates the textural parameters from the curve generated by such a test, as follows: hardness $(\mathrm{N})$ is given as the first force peak if there are only two peaks on the TPA curve, or the second peak if there are three peaks. Adhesiveness $(\mathrm{N} \mathrm{s})$ is the negative area between the point at which the first curve reaches a zero force value after the first compression and the start of the second curve. Springiness is calculated as the ratio of the distance or time from the start of the second area up to the second probe reversal vs. the distance or time between the start of the first area and the first probe reversal. Cohesiveness is calculated as the ratio of the positive force area during the second compression portion to the positive force area during the first compression. Gumminess $(\mathrm{N})$ is calculated as hardness $\mathrm{x}$ cohesiveness. For performing the firmness tests, a spreadability rig was used, consisting of a $45^{\circ}$ conical perspex probe $(\mathrm{P} / 45 \mathrm{C})$ that penetrated a conical sample holder containing $7 \pm 0.1 \mathrm{~g}$ of mashed potato. Tests were done at a deformation rate of $180 \mathrm{~mm} \mathrm{~min}^{-1}$. There were four replicates for each experimental unit. The force time curve was used to calculate the firmness $(\mathrm{N})$, the area under the force/time curve $(\mathrm{N} \mathrm{s})$, the firmness per gram of product $\left(\mathrm{N} \mathrm{g}^{-1}\right)$, the area under the curve per displaced volume $\left(\mathrm{N} \mathrm{s} \mathrm{mm}^{-3}\right)$ and the average force $(\mathrm{N})$.

\section{Oscillatory rheological measurements}

A Bohlin (Bohlin Instruments Ltd, Gloucestershire, UK) CVR 50 controlled stress rheometer was used to conduct small amplitude oscillatory shear experiments (SAOS) and steady shear using a 
plate-plate sensor system with a $2 \mathrm{~mm}$ gap (PP40, $40 \mathrm{~mm}$ ) and a solvent trap to minimise moisture loss during tests. Samples were allowed to relax for $5 \mathrm{~min}$ before rheological measurements were made, such as equilibration time for recovery and development of sample structure after loading the same on the sensor system. Temperature control at $55^{\circ} \mathrm{C}$ was achieved with a Peltier Plate system $\left(-40\right.$ to $\left.+180{ }^{\circ} \mathrm{C}\right)$ (Bohlin Instruments Ltd, Gloucestershire, UK). Dynamic shear data were obtained over the range 0.1-100 rad.s ${ }^{-1}$ at very low strains. The applied strains were dependent on product types but were mostly below $10^{-3}$. The linear viscoelastic domain was determined for each sample from stress sweeps at $1 \operatorname{rad}^{-1}{ }^{-1}$. In preliminary experiments, the effects of three frequencies, $0.1,1$, and $10 \mathrm{rad}_{\mathrm{s}}{ }^{-1}$, on the linear viscoelastic domain were investigated; there was little apparent difference in the domains obtained at these three frequencies. Bohlin software was used to obtain experimental data and to calculate the phase angle $(\delta)$, the complex modulus $\left(G^{*}\right)$, the storage modulus $\left(G^{\prime}\right)$, the loss modulus $\left(G^{\prime \prime}\right)$ and the complex viscosity $\left(\eta^{*}\right)$ at each test frequency (Alvarez et al., 2004).

\section{Sensory analysis}

Sensory TPA was done by a five-member panel trained specifically in sensory analysis of mashed potato. The Texture Profile system (UNE 87025, 1996) was modified to evaluate frozen mashed vegetables (Canet et al., 2005a). Scores for sensory attributes were based on a 9-point descriptive intensity scale converted to a 1-9 numerical scale for statistical analysis, with $1=$ not detectable and 9 = extremely intense. Profile attributes are classified in four groups: attributes perceived before putting the sample in the mouth (granularity and moisture); attributes perceived at the time of putting the sample in the mouth (adhesiveness, denseness, homogeneity, moisture and 
firmness); attributes perceived at the time of preparing the sample in the mouth for swallowing (cohesiveness, adhesiveness, fibrousness); attributes perceived during final and residual phases of mastication (ease of swallowing, palate coating and fibrousness). Mashed potato samples were also subjected to an overall acceptability test based on all sensory attributes (texture, colour, taste), on a 9-point hedonic scale (9 = like extremely, $1=$ dislike extremely).

\section{Experimental design and data analysis}

The effect of the temperature and time of LTB on the quality of both fresh and frozen/thawed mashed potato was studied using Response Surface Methodology (RSM), which made it possible to establish optimum LTB temperature and time conditions so as to produce mashed potato with different optimum quality parameters. The upper and lower levels of the two factors LTB temperature and LTB time were initially based on published information from potatoes (Moledina et al., 1978; Alvarez \& Canet, 1999b; Canet et al., 2005b). A first series of experiments was conducted following the central composite rotatable experimental design, with blanching temperature ranging between 55 and $65^{\circ} \mathrm{C}$ and blanching time ranging between 50 and 80 min as independent variables, based on previous findings (Canet et al., 2005b), although the results have been omitted for the sake of brevity. Statgraphics ${ }^{\circledR}$ software version 5.0 (STSC Inc., Rockville, MD, USA) was used to provide the experimental designs, calculate equations, do statistical evaluation and print out data. A central composite rotatable experimental design was used with blanching temperature ranging between 60 and $70{ }^{\circ} \mathrm{C}$ and blanching time ranging between 20 and $40 \mathrm{~min}$ as independent variables (Table 1). In the design, coded variables are related to uncoded ones by equations: $X_{1}=\left(\xi_{1}-\mathrm{a}\right) / \mathrm{b}$ and $\mathrm{X}_{2}=\left(\xi_{2}-\mathrm{c}\right) / \mathrm{d}$, where $\mathrm{X}_{1}, \mathrm{X}_{2}, \xi_{1}$ and $\xi_{2}$ are 
temperature and time variables in coded and uncoded mode respectively; a, c are the central points of the uncoded temperature and time ranges studies $\left(65^{\circ} \mathrm{C}\right.$ and $30 \mathrm{~min}$, respectively); b, $\mathrm{d}$ are calculated as the difference between the mentioned central points and the upper and lower conditions of the uncoded temperature and time ranges studies $\left(5^{\circ} \mathrm{C}\right.$ and $10 \mathrm{~min}$, respectively).

The design required 13 variable combinations that were performed in random order, including 5 replicates of the centre region to generate a quadratic response surface (Myers \& Montgomery, 1995; Alvarez \& Canet, 1999b; Alvarez et al., 1999). In both fresh and frozen/thawed mashed potato, each treatment combination was repeated twice and all the results averaged. Range finding experiments were performed at the outset of this work in order to ascertain what blanching temperature and time ranges could be applied to the mashed potatoes so that the product would be acceptable to consumers on the basis of sensory attributes (texture, colour, and taste).

The following dependent variables (responses) were analysed by RSM: TPA, firmness, oscillatory parameters, $\mathrm{L}^{*} / \mathrm{b}^{*}$ ratio from colour measurements and overall acceptability. Data were analysed for coefficient of determination $\left(R^{2}\right)$ value, probability, lack-of-fit test, and regression coefficients $\left(b_{0}, b_{1}, b_{2}, b_{11}, b_{22}\right.$ and $\left.b_{12}\right)$. The relationship between the dependent and independent variables was expressed in terms of a second order polynomial equation having the form:

$Y=b_{0}+b_{1} X_{1}+b_{2} X_{2}+b_{11} X_{1}^{2}+b_{22} X_{2}^{2}+b_{12} X_{1} X_{2}$

where $Y=$ response, $X_{1}=$ temperature of blanching $\left({ }^{\circ} \mathrm{C}\right), X_{2}=$ time of blanching $(\min )$ and $b_{0}, b_{1}$, $b_{2}, b_{1}{ }^{2}, b_{2}{ }^{2}, b_{12}=$ coefficients (constants) which measure linear, quadratic and interaction effects (Sim et al., 2004). The optimum ranges for the two factors tested (temperature and time of blanching) were interpreted from response surfaces. The stationary points of $X_{1}$ and $X_{2}$ 
respectively, which give the optimum response, were calculated, as well as the value of the estimated response at this stationary point (Myers \& Montgomery, 1995). For both fresh and frozen/thawed mashed potato, the differences in instrumental and sensory parameters for the different blanching temperature/time conditions of the central composite design and controls were studied prior to optimisation by means of one-way analysis of variance, using the least significant difference tests with a $99 \%$ confidence interval for comparison of instrumental parameters and with a $95 \%$ confidence interval for comparison of sensory attributes.

\section{Results and discussion}

\section{Instrumental parameters}

Data were compiled for low-temperature blanching (LTB) combinations and mean values of the corresponding colour parameters and dry matter content of the fresh and frozen/thawed-mashed potato are shown in the Table 1. Unblanched samples and unblanched samples with added starch were treated as controls. LTB conditions significantly affected all the measured parameters $(P<0.001)$ in both the fresh and the frozen/thawed-mashed potatoes. In general, in fresh mashed potato most of the blanching temperature and time conditions reduced the $\mathrm{L}^{*}$ (lightness), $\mathrm{a}^{*}$ (redness) and $\mathrm{b}^{*}$ (yellowness) values but increased the $\mathrm{L}^{*} / \mathrm{b}^{*}$ ratio of the samples with respect to the controls. Thus, LTB prior to cooking produced a lighter-coloured mashed potato (higher $\mathrm{L}^{*} / \mathrm{b}^{*}$ ratio) than cooking alone; this was to be expected given that LTB causes sizeable losses of colour related to (Pala, 1983). Colour is often the first parameter by which a consumer judges a food product before purchase (Faulks \& Griffths, 1983). However, this lightening should not be 
of major importance, since anyone presented with a blanched mashed potato is unlikely to have an unblanched fresh sample to compare it against. In frozen-thawed mashed potato (Table 1), blanching also significantly increased the $\mathrm{L}^{*} / \mathrm{b}^{*}$ ratio of the product with respect to frozenthawed controls, but the ratios in the blanched fresh and blanched frozen/thawed samples were quite similar. In natural and commercial mashed potato, $\mathrm{L}^{*} / \mathrm{b}^{*}$ values were lower than in the fresh controls after freezing and thawing of the samples, so that frozen-thawed were darker than fresh products (Alvarez et al., 2005). Also, frozen mashed potato made from reconstituted potato flakes was darker than non-frozen mashed potato (O'Leary et al., 2000). The results indicate that blanching prior to cooking had a positive effect in that it reduced the differences in brightness between fresh and frozen-thawed unblanched mashed potato. Addition of starch to fresh unblanched mashed potato caused samples to darken (lower $\mathrm{L}^{*} / \mathrm{b}^{*}$ ratio), although differences were not detected after freezing and thawing.

In both fresh and frozen/thawed mashed potato, dry matter percentages were lower in the blanched samples than in the corresponding controls. Blanching is known to increase the permeability of cytoplasmic membranes, allowing the blanch water to penetrate cells and intercellular spaces, driving out gases and other volatile compounds (Canet \& Hill, 1987), causing losses of soluble substances such as vitamins, salts and sugars, and increasing the moisture content of the samples. In general terms, dry matter contents were lower in the fresh than in their counterpart frozen/thawed mashed potatoes in both the blanched and the control samples, confirming previous findings (Downey, 2003; Alvarez et al., 2005). Ice crystal growth leads to contraction and disruption of starch granules, while cell wall disruption leads to a redistribution of amylose and amylopectin leading to local concentration differences. The locally concentrated amylopectin is prone to molecular aggregation leading to shrinkage and water 
expulsion (Kim \& Eliasson, 1993). Addition of starch to fresh control increased moisture content, which could be explained simply in terms of starch's ability to immobilize free water, but after freezing and thawing, the differences in the dry matter percentages between both controls were non-significant.

In both fresh and frozen/thawed mashed potatoes, blanching temperature and time significantly $(P<0.001)$ affected all the TPA and firmness parameters (Table 2). For the fresh and frozen/thawed blanched mashed potato, high TPA and firmness parameters were recorded at the replicated centre points $\left(65^{\circ} \mathrm{C}, 30 \mathrm{~min}\right)$, as well as at the design points 11,12 and 13 , for which the blanching temperature was $>65{ }^{\circ} \mathrm{C}$. Note, as in both fresh and frozen/thawed blanched mashed potato most of the parameter values at the replicated design point 7 were lower than at the other replicated points. When blanching temperature was $<65^{\circ} \mathrm{C}$, the parameter values were lower than those obtained in the unblanched controls, showing that blanching under certain conditions caused softening of the mashed potato. In contrast, for both fresh and frozen/thawed blanched mashed potato, TPA (except hardness) and firmness parameters recorded at four of the replicated centre points were higher than in the controls: thus, blanching at $65^{\circ} \mathrm{C}$ for $30 \mathrm{~min}$ had the effect of thickening mashed potatoes. The results indicate that in mashed potato prepared directly, after blanching under certain conditions the cell walls were stronger than those of the cooked cells without the pre-treatment, where solubilisation was more complete; moreover, this effect was detected even after freezing and thawing of the samples. In any case, the differences between blanched and control samples were not statistically significant for most of the parameters in the frozen/thawed-mashed potato, which means that subsequent freezing and thawing of the samples masked differences between blanched and unblanched mashed potatoes. Comparison of the two unblanched controls shows that the addition of starch to fresh product significantly 
reduced hardness and gumminess values, and increased all other parameters, although the only parameter that differed significantly between the controls was. Also, addition of carrageenan to fresh potato purées increased maximum resistance values i.e. thickened the purée (Downey, 2002). After freezing and thawing of the unblanched samples, all the firmness parameters in the samples with starch added were again higher, although the controls only differed significantly in firmness parameters. Also, parameter values were higher in the frozen/thawed control with added starch than in its fresh counterpart. On the other hand, addition of different cryoprotectants (whey protein concentrate, sodium caseinate, guar and xanthan) to fresh mashed potato reduced the maximum resistance after freezing by two different methods (Downey, 2002); this could have been due to the higher freezing rate used in this study. Finally, in both controls and in all the blanched samples, TPA (except hardness) and firmness parameters were higher in the frozen/thawed mashed potatoes than in their fresh counterparts.

In both fresh and frozen/thawed mashed potatoes, blanching temperature and time significantly $(P<0.001)$ affected all the oscillatory parameters (Table 3$)$. For the fresh and frozen/thawed blanched mashed potato, the lowest phase angle and the highest modulus and complex viscosity values were recorded in the blanched samples at the replicated centre points $\left(65^{\circ} \mathrm{C}, 30 \mathrm{~min}\right)$ and in the blanched samples at temperature $>65^{\circ} \mathrm{C}$. Dynamic measurements also revealed the thickening effect produced by blanching at $65^{\circ} \mathrm{C}$ for $30 \mathrm{~min}$, chiefly in many of the repeated replicates (design points 5 and 9). Mechanistic models for this phenomenon have often centred on the activation of the PME enzyme. What the enzyme does is to demethylate the carboxymethyl groups of pectic polysaccharide chains. The decrease in the degree of methylation may in turn trigger different processes related to texture and firmness, such as crosslinking by $\mathrm{Ca}^{2+}$ ions, increased hydration at the demethylated sites, reduced susceptibility for heat induced 
$\beta$-degradation of pectins and enhanced shielding and repulsion forces by the electric charges within the biopolymer matrix of the cell walls. Recently, Canet et al., (2005b) found a high correlation between increased PME activity and firmness retention in the optimisation of lowtemperature blanching applied prior to freezing and cooking of potato tissues (cv. Kennebec), proving that the enzyme was one of the main contributors to firmness of frozen potatoes. Based on these findings, it appears obvious that the reinforcement detected by the instrumental parameters and caused in the cell walls of the potato cells by blanching at $65^{\circ} \mathrm{C}$ for $30 \mathrm{~min}$ could be ascribed to PME enzyme activation rendering the cell binding less degradable.

A comparison of the two unblanched controls (Table 3) shows that in both fresh and frozen/thawed mashed potato, the addition of starch significantly reduced the moduli and the complex viscosity of the samples. However, in all the blanched and unblanched samples, oscillatory parameters were higher in the fresh mashed potatoes than in their frozen/thawed counterparts. However, as noted earlier, all the other TPA and firmness parameters were higher in the frozen/thawed than in the fresh samples, and it therefore seems obvious that different parameters are detecting different compositional and structural changes caused by processing during the manufacture of mashed potato. While the texture of edible tissue is usually conferred by the cell wall and its middle lamella, and is affected by changes in cell adhesion and pectin degradation, in macerates the apparent viscosity is affected by cell friction rather than cell adhesion (Shomer et al., 1993). While firmness parameters, together with adhesiveness, springiness, cohesiveness and gumminess from texture profile analysis, seem to measure cell adhesion in the mashed potatoes, oscillatory parameters and hardness could measure the intercellular friction, which was less after freezing even at a very rapid rate, in spite of blanching prior to cooking. 


\section{Sensory analysis}

Tables 4 and 5 show the effect of blanching temperature and time on the panellists' average scores for sensory attributes from texture profile analysis and overall acceptability in comparison with fresh and frozen/thawed controls. LTB conditions significantly affected all the sensory attributes scored $(P<0.01)$, either in fresh or in frozen/thawed-mashed potato. For fresh product, practically no significant differences were found for granularity and moistness scores between controls and blanched samples at the replicated centre points $\left(65^{\circ} \mathrm{C}, 30 \mathrm{~min}\right)$. For frozen/thawed product, granularity increased significantly and moisture decreased significantly with respect to unblanched control after blanching at $65^{\circ} \mathrm{C}$ for $30 \mathrm{~min}$. Panellists also detected lower granularity and higher moisture in fresh mashed potato; this confirmed the results from dry matter data and indicated a negative effect caused by freezing and thawing which rendered granularity more appreciable and dried the samples. For fresh mashed potato, again there were practically no significant differences in the scores between controls and pre-treated samples $\left(65^{\circ} \mathrm{C}, 30 \mathrm{~min}\right)$ for sensory attributes perceived at the time of putting the sample in the mouth. For frozen/thawed mashed potato, moisture decreased significantly, again corroborating results from dry matter sample contents, and firmness increased significantly with respect to unblanched control after blanching at $65{ }^{\circ} \mathrm{C}$ for $30 \mathrm{~min}$. In both fresh and frozen/thawed mashed potato, some significant differences were observed between scores given to controls and pre-treated samples $\left(65^{\circ} \mathrm{C}, 30\right.$ min) for sensory attributes perceived at the time of preparing the sample for swallowing. The chief point of note is that the score for cohesiveness and adhesiveness was higher in the frozen/thawed samples, which was consistent with values obtained for instrumental parameters under the same conditions. For fresh product, there were significant differences in the scores for 
fibrousness assigned to controls and to samples pre-treated at $65^{\circ} \mathrm{C}$ for $30 \mathrm{~min}$ (Table 5), with higher attribute scores going to the latter. For frozen/thawed mashed potato, differences in the scores for ease of swallowing and palate coating were significant, the samples blanched at $65^{\circ} \mathrm{C}$ for $30 \mathrm{~min}$ scoring lower for ease of swallowing and higher for palate coating than the unblanched control.

Finally, for fresh mashed potato the panellists scored the samples blanched at $65{ }^{\circ} \mathrm{C}, 30$-min significantly lower for overall acceptability than the unblanched controls. Of the blanched samples, panellists scored the samples blanched at $70{ }^{\circ} \mathrm{C}, 20$-min (design point 11) highest for overall acceptability; this was not significantly different from the scores of the control samples. For frozen/thawed mashed potato, of the blanched samples panellists scored the samples blanched at $70{ }^{\circ} \mathrm{C}, 20$-min and $72{ }^{\circ} \mathrm{C}, 30$-min (design points 11 and 13) highest for overall acceptability; again, this score was not significantly different from the score of the unblanched frozen/thawed control 1 without added starch. Panellists scored the frozen/thawed samples blanched at $65{ }^{\circ} \mathrm{C}$, 30-min significantly lower for overall acceptability than the unblanched control 1 (except for one of the replicated points), although scores were not significantly different from the control 2 with added starch. Interestingly, scores for overall acceptability were higher in the frozen/thawed blanched mashed potatoes than in their fresh counterparts, highlighting the potential of precooking blanching to improve the quality of mashed potato that is subjected to freezing and thawing.

\section{Optimisation of blanching conditions}


Based on the results of the first statistical analysis, RSM was used to find the optimum temperature and time of blanching prior to cooking for $\mathrm{L}^{*} / \mathrm{b}^{*}$ ratio, TPA, firmness, oscillatory parameters and overall acceptability in the fresh and frozen/thawed mashed potato. Regression coefficients of each response model fitted were tested for significance and are presented in Table 6, together with their coefficients of determination, $R^{2}, F$-Ratios and $P$-values and lack-of-fit tests. Response models of instrumental parameters which gave $R^{2}$-values $<0.750$ have been omitted, since these models showed very low percentages of explained variability, indicating a significant lack of fit (Henika, 1982). In both fresh and frozen/thawed mashed potatoes, $\mathrm{L}^{*} / \mathrm{b}^{*}$ ratio models had significant linear and quadratic terms for temperature ( $b_{1}$ and $b_{11}$ respectively), a significant linear term for time $\left(b_{2}\right)$, and the interaction was significant in both models $\left(b_{12}\right)$. For this colour parameter, $R^{2}$-values were good $(>0.750)$, but the $\mathrm{L}^{*} / \mathrm{b}^{*}$ model fitted for the fresh product had a significant lack-of-fit test. In fresh mashed potato for TPA parameters, independent variables had approximately the same effect on hardness and gumminess, with a significant linear term for temperature $\left(b_{1}\right)$ and significant quadratic terms for temperature and time $\left(b_{11}\right.$ and $b_{22}$ respectively). $R^{2}$-values were good $(>0.750)$ for both TPA parameters, with no significant lackof-fit tests. For firmness parameters, independent variables also had the same effect on the area, area per displaced volume and average force measured in the fresh product, with only slightly significant linear and quadratic terms for temperature, similar quite low $R^{2}$-values (approximately 0.750), but non-significant lack-of-fit tests. In fresh mashed potato, oscillatory parameters were linearly affected by variations in blanching temperature and quadratically affected by variations in both independent variables. Loss modulus $\left(G^{\prime \prime}\right)$ was also linearly affected by variations in blanching time. The $R^{2}$-values are good for all the oscillatory parameters $(>0.750)$ with no significant lack-of-fit test for the rheological parameters. Of all the TPA and firmness parameters 
in the frozen/thawed mashed potato, only the response model fitted for cohesiveness is shown, with a significant linear term for temperature, significant quadratic terms for temperature and time and significant interaction of the two factors. Response models for the rest of the TPA parameters and all the firmness parameters gave $R^{2}$-values $<0.750$, and therefore have been omitted from the Table 6 . The $R^{2}$-value for cohesiveness model was good (>0.750), but the lackof-fit test for this response was significant. As found for fresh mashed potato, independent variables more significantly affected oscillatory parameters, which were linearly affected by variations in blanching temperature and quadratically affected by variations in both independent variables. Except for loss modulus (G"), all the other oscillatory parameters were also slightly and linearly affected by variations in time. Again, the $R^{2}$-values are good for all the oscillatory parameters $(>0.750)$, with no significant lack-of-fit test for the rheological parameters.

Finally, in fresh mashed potato, overall acceptability was linearly affected by variations in blanching temperature and time and quadratically affected by variations in both independent variables. The $R^{2}$-value was very good (>0.850), but there was a significant lack-of-fit test. Models with high $R^{2}$-values and significant lack-of-fit tests indicate that higher-order models are probably required to describe the effects of the independent variables and would be used only for trends analysis (Henika, 1982; Alvarez et al., 1999b). In frozen/thawed mashed potato, overall acceptability was linearly affected by variations in blanching temperature and time and quadratically affected by variations in blanching time. For overall acceptability of the frozen/thawed product, the $R^{2}$-value was the highest (>0.980), with no significant lack-of-fit test. Only models with high percentages of explained variability $\left(R^{2}>0.850\right)$ and non-significant lackof-fit tests would be considered sufficiently accurate to make predictions (Henika, 1982). Between models fitted in this study, only $\mathrm{L}^{*} / \mathrm{b}^{*}$ ratio and overall acceptability models in the 
frozen/thawed product definitely fulfil both conditions. Most of models fitted had $R^{2}$-values in the range $\left(0.750<R^{2}<0.850\right)$. Among the common causes of poor modelling are a skewed response distribution, curvature in the relationship between a response variable and a design factor, large between-replicate variation and outlying experiments (Downey, 2003). Examination of the standardised residuals produced by the models showed no outlying experimental points, while ANOVA demonstrated the significance of the fitted regression models. The large betweenreplicate variation is the most likely cause of the poor modelling found, since all the parameter values were lower at design point 7 than at the rest of the replicated points. Stepwise regression analysis was performed for the dependent variables. This analysis eliminates the insignificant coefficients on the basis of $P$-values, then the models can be reduced. However, reduced models did not present higher $R^{2}$-values and, therefore the full models fitted were used for further analysis in order to be able to obtain stationary points. The fact that blanching temperature and time had a quadratic effect on most of the parameters indicated the existence of an optimum region for both independent variables, and the aim was to test the closeness or distance of the optimum responses obtained from the different dependent variables. In this way, the best fitted models were used in both fresh and frozen/thawed mashed potato to generate surface responses to identify the main effects of blanching temperature and time (Figs 1-3). In LTB for fresh mashed potato, L*/b* ratio (Fig. 1a), gumminess (Fig. 1b), average force (Fig. 1c), complex viscosity (Fig. 1d) and overall acceptability (Fig. 3a), and in LTB for frozen/thawed mashed potato cohesiveness (Fig. 2b), loss modulus (Fig. 2c) and complex viscosity (Fig. 2d), all increased with temperature and time up to certain levels beyond which both variables decreased, thus defining an optimum region. For the frozen/thawed product, response surface $\mathrm{L}^{*} / \mathrm{b}^{*}$ ratio (Fig. 2a) presents a saddle-effect, thus identifying a set of blanching temperature and time values which will produce 
the maximum lightening. From the shape of the plots (Fig. 3a, b) it seems reasonable to assume a relationship between increase in overall acceptability and firmer texture and structure in the mashed potato, indicating that a firmer product represents a quality gain and is a desired goal. This finding contradicts previous studies, where a reduction in maximum resistance values in potato purée represented a product with a softer mouth-feel and was reported by sensory panellists as desirable (Downey, 2002).

Values (stationary points) which give optimum combinations for each quality parameter were calculated (Table 7). In fresh mashed potato, the critical values of average force showing maximum firmness, complex viscosity showing maximum thickening and overall acceptability showing maximum preference for the product lay in the region delimited by the ranges studied; they were close to $70{ }^{\circ} \mathrm{C}$ and $30 \mathrm{~min}$ for average force and complex viscosity and close to $70{ }^{\circ} \mathrm{C}$ and 20 min for overall acceptability. In frozen/thawed mashed potato also, the critical values of stationary points for $\mathrm{L}^{*} / \mathrm{b}^{*}$ showing the lightest product and for loss modulus and complex viscosity showing maximum thickening were close to $70{ }^{\circ} \mathrm{C}$ and $30 \mathrm{~min}$. One or both critical values were outside the region delimited by the range studied, for $\mathrm{L}^{*} / \mathrm{b}^{*}$ ratio and gumminess in the fresh product and for cohesiveness and overall acceptability in the frozen/thawed product, and therefore the response given by these models at stationary points was not estimated. Blanching at $70{ }^{\circ} \mathrm{C}$ for $25 \mathrm{~min}$ further tested the accuracy of the models for the quality parameters (Table 8), arriving at a compromise solution between stationary points for textural and rheological parameters and overall acceptability. Predicted values for the models were closer to experimental values for the fresh mashed potatoes than for the frozen/thawed-mashed potatoes. In any event it should be stressed that the predictive ability of the models developed for most of the parameters is poor, and therefore they should not be used for predictive purposes. In both fresh and 
frozen/thawed mashed potatoes, models fitted for complex viscosity $\left(\eta^{*}\right)$ presented high $R^{2}$, nonsignificant lack-of-fit tests and a small gap between experimental and predicted values; this may therefore be considered the most suitable parameter for representing the rheological behaviour of fresh and frozen/thawed mashed potato subjected to LTB prior to cooking.

\section{Conclusions}

LTB prior to cooking produced a lighter fresh or frozen/thawed mashed potato than cooking alone, but reduced differences in brightness between fresh and frozen/thawed mashed potato. Addition of starch to fresh mashed potato caused darkening of the samples and increased their moisture content, although differences were not significant after freezing and thawing. Dry matter contents were lower in the fresh than in their counterpart frozen/thawed mashed potatoes in both blanched and control samples. Results of the different instrumental parameters indicated that in both fresh and frozen/thawed-mashed potato, blanching at $<65{ }^{\circ} \mathrm{C}$ produced a softening of the product with respect to the unblanched controls, while blanching at $65{ }^{\circ} \mathrm{C}$ for $30 \mathrm{~min}$ had the effect of thickening the mashed potatoes, which could be the result of PME enzyme activation rendering the cell binding less degradable. Scores for overall acceptability were higher in the frozen/thawed blanched mashed potatoes than in their fresh counterparts, highlighting the potential of blanching to improve the quality of mashed potatoes that are subjected to freezing and thawing. Stationary points for instrumental parameters showing maximum thickening had critical temperatures (approximately $67-69{ }^{\circ} \mathrm{C}$ ) and times (approximately $26-30 \mathrm{~min}$ ) in the ranges used for each independent variable for both fresh and frozen/thawed mashed potato. The results showed a very high correlation between structural reinforcement and overall acceptability in 
optimum experimental blanching conditions. For fresh and frozen/thawed mashed potato the panellists scored the samples blanched at $65^{\circ} \mathrm{C}$, 30-min significantly lower for overall acceptability than the unblanched controls, possible due to excessive thickening. From our point of view, it would be a quality gain and a desirable goal to make mashed potatoes which, after freezing and thawing and even after a long term in frozen storage, scored as well as fresh control for overall acceptability. It is clearly important to obtain information on the effects of blanching prior to cooking, whether applied alone or in combination with cryoprotectant treatments, in mashed potatoes frozen/thawed by different methods. This approach (LTB prior to cooking) may have potential for designing mashed potatoes with specified colour and texture depending on their following treatment. 
Acknowledgements The authors wish to thank to the Ministerio de Educación y Ciencia for financial support (AGL2004-01780) 


\section{References}

Alvarez, M.D., Canet, W. \& Tortosa, M.E. (1997). Effect of freezing rate and programmed freezing on rheological parameters and tissue structure of potato (cv. Monalisa). Lebensmittel-Untersuchung und-Forschung A, 204, 356364.

Alvarez, M.D. \& Canet, W. (1999a). Rheological properties of mashed potatoes made from dehydrated flakes: effect of ingredients and freezing. European Food Research and Technology, 209, 335-342.

Alvarez , M.D. \& Canet, W. (1999b). Optimization of stepwise blanching of frozen-thawed potato tissues (cv. Monalisa). European Food Research and Technology, 210, 102-108.

Alvarez, M.D., Morillo M.J. \& Canet, W. (1999). Optimisation of freezing process with pressure steaming of potato tissues (cv. Monalisa). Journal of the Science of Food and Agriculture, 79, 1237-1248.

Alvarez, M.D., Fernández, C. \& Canet, W. (2004). Rheological behaviour of fresh and frozen potato puree in steady and dynamic shear at different temperatures. European Food Research and Technology, 218, 544-553.

Alvarez, M.D., Canet, W. \& Fernández, C. (2005). Effect of freezing/thawing conditions and long-term frozen storage on the quality of mashed potatoes. Journal of the Science of Food and Agriculture (in press).

Anzaldúa-Morales, A., Bourne, M.C. \& Shomer, I. (1992). Cultivar, specific-gravity and location in tuber affect puncture force of raw potatoes. Journal of Food Science, 57, 1353-1356.

Bartolome, L.G. \& Hoff, J.E. (1972). Firming of potatoes: biochemical effect of preheating. Journal of Agricultural and Food Chemistry, 20, 266-270.

Brown, A.M. \& Morales, J.A.W. (1970). Determination of blanching conditions for frozen parfried potatoes. American Potato Journal, 47, 321-325.

Canet, W., Espinosa, J. \& Ruiz Altisent, M. (1982). Effects of stepwise blanching on the texture of frozen potatoes measured by mechanical tests. In Refrigeration Science and Technology (edited by International Institute of Refrigeration). Vol. 4, Pp 284-289, Sofia, Bulgaria.

Canet, W. \& Hill, M. (1987). A comparison of several blanching methods on the texture and ascorbic acid content of frozen potatoes. International Journal of Food Science and Technology, 22, 273-277. 
Canet, W., Alvarez, M.D., Fernández, C. \& Tortosa M.E. (2005a). The effect of sample temperature on instrumental and sensory properties of mashed potato products. International Journal of Food Science and Technology, 40 , 481-493.

Canet, W., Alvarez, M.D. \& Fernández, C. (2005b). Optimization of low-temperature blanching for retention of potato firmness: effect of previous storage on compression properties. European Food Research and Technology, 221, 423-433.

CIE. (1978). Recommendations on uniform colour spaces-colour difference equations, psychometric colour terms. Supplement No. 2 to CIE Publication No. 15(E-1-3.1) 1971/(TC-1-3). CIE, Paris.

Downey, G. (2002). Quality changes in frozen and thawed, cooked puréed vegetables containing hydrocolloids, gums and dairy powders. International Journal of Food Science and Technology, 37, 869-877.

Downey, G. (2003). Effects of cryoprotectant mixtures on physical properties of frozen and thawed puréed cooked potatoes: some introductory studies. International Journal of Food Science and Technology, 38, 857-868.

Faulks, R.M. \& Griffths, N.M. (1983). Influence of variety, site and storage on the physical, sensory and compositional aspects of mashed potato. Journal of the Science of Food and Agriculture, 34, 979-986.

Gil, M.J. (1991). Estudio del efecto de la fricción, dimensión de las muestras y velocidades de deformación en ensayos de compresión uniaxial de alimentos sólidos. PhD Thesis, Universidad Politécnica de Madrid

Henika, R.G. (1982). Use of response surface methodology in sensory evaluation. Food Technology, $36,96$.

Kim, H.R. \& Eliasson, A.-C. (1993). Changes in rheological properties of hydroxypropyl potato starch paste during freeze-thaw treatments. II. Effect of molar substitution and cross-linking and thermal (DSC) properties. Journal of Texture Studies, 24, 199-213.

Moledina, K.H., Fedec, P., Hadziyev, D. \& Ooraikul, B. (1978). Ultrastructural changes in potato during potato granule process as viewed by SEM. Starch/Stärke, 30, 191-199.

Myers, R.H. \& Montgomery, D.C. (1995). Response surface methodology. John Wiley \& Sons, Inc., New York

Novais, A., Hanson, S.W. \& Ryley, J. (1982). The texture of mashed potatoes in catering I. The background. The contribution of hedonic texture to overall preference. Lebensmittel-Wissenschaft und-Technologie, 15, 295 -302.

O’Leary, E., Gormley, T.R., Butler, F. \& Shilton, N. (2000). The effect of freeze-chilling on the quality of readymeal components. Lebensmittel-Wissenschaft und-Technologie, 33, 217-224. 
Pala, M. (1983). Stepwise blanching and its importance in freezing of vegetables. In Refrigeration in the service of man. XVIth International Congress of Refrigeration. Paris. Vol. 3, pp 631-638.

Redmond, G.A., Butler, F. \& Gormley, T.R. (2002). The effect of freezing conditions on the quality of freeze-chilled reconstituted mashed potato. Lebensmittel-Wissenschaft und-Technologie, 35, 201-204.

Rico, R., Alvarez, M.D. \& Canet, W. (1995). Sistema de adquisición y análisis de datos. Eurofach Electrónica, 18, 6065.

Shomer, I.,Rao, M.A., Bourne, M.C. \& Levy, D. (1993). Impact of temperature and cellulose treatments on rheological behavior of potato tuber cell suspensions. Journal of the Science of Food and Agriculture, 63, $245-250$.

Sim, C.W., Muhammad, K., Yusof, S., Bakar, J. \& Hashim, D.M. (2004). The optimization of conditions for the production of acid-hydrolysed winged bean and soybean proteins with reduction of 3-monochloropropane-1,2diol (3-MCPD). International Journal of Food Science and Technology, 39, 947-958.

Smith, O. (1987). Transport and storage of potatoes. In: Potato processing (edited by W. F. Talburt \& O. Smith). Pp 203-285. New York: Van Nostrand Reinhold.

UNE 87025 (1996). Manual de análisis sensorial. Tomo I - Alimentación. Pp. 167-186. Madrid: Aenor. 


\section{Figure legends}

Figure 1 Instrumental parameter response surfaces as functions of blanching temperature and time for fresh mashed potato: (a) L*/b* ratio from colour measurement; (b) gumminess from TPA test; (c) average force from firmness test; (d) complex viscosity from oscillatory rheological test.

Figure 2 Instrumental parameter response surfaces as functions of blanching temperature and time for frozen/thawed mashed potato: (a) $\mathrm{L}^{*} / \mathrm{b}^{*}$ ratio from colour measurement; (b) cohesiveness from TPA test; (c) loss modulus from oscillatory rheological test; (d) complex viscosity from oscillatory rheological test.

Figure 3 Overall acceptability response surfaces as functions of blanching temperature and time: (a) for fresh mashed potato; (b) for frozen/thawed mashed potato. 
Table 1 Coded and uncoded variables of the response surface design and colour parameters and dry matter content: fresh and frozen/thawed mashed potatoes with the different blanching combinations, and controls

\begin{tabular}{|c|c|c|c|c|c|c|c|c|c|}
\hline \multirow{2}{*}{$\begin{array}{l}\text { Design } \\
\text { point }\end{array}$} & \multicolumn{2}{|c|}{ Coded } & \multicolumn{2}{|c|}{ Uncoded } & \multirow[t]{2}{*}{$\mathbf{L}^{*}$} & \multirow[t]{2}{*}{$\mathbf{a}^{\star}$} & \multirow[t]{2}{*}{$\mathbf{b}^{\star}$} & \multirow[t]{2}{*}{$\mathbf{L}^{\star} / \mathbf{b}^{\star}$} & \multirow[t]{2}{*}{ Dry matter (\%) } \\
\hline & $X_{1}$ & $X_{2}$ & $\xi_{1}:$ Temperature $\left({ }^{\circ} \mathrm{C}\right)$ & $\xi_{2}:$ Time (min) & & & & & \\
\hline \multicolumn{10}{|c|}{ Fresh mashed potatoes } \\
\hline \multirow{2}{*}{\multicolumn{5}{|c|}{$\begin{array}{l}\text { Fresh control1 }{ }^{*} \\
\text { Fresh control2 }\end{array}$}} & $63.56 \mathrm{a}$ & $-6.82 d$ & $11.30 \mathrm{a}$ & $5.63 \mathrm{~b}$ & $19.51 \mathrm{a}$ \\
\hline & & & & & $60.21 \mathrm{e}$ & $-7.68 \mathrm{a}$ & $11.53 \mathrm{a}$ & $5.23 \mathrm{a}$ & $18.02 b$ \\
\hline 1 & -1.41 & 0 & 57.93 & 30 & $57.47 \mathrm{j}$ & $-6.28 h$ & $7.78 \mathrm{~d}$ & $7.40 \mathrm{~d}$ & $16.04 \mathrm{e}-\mathrm{g}$ \\
\hline 2 & -1 & -1 & 60 & 20 & $56.67 \mathrm{k}$ & $-6.55 e, f$ & $8.06 b-d$ & $7.04 \mathrm{c}$ & $17.15 \mathrm{c}$ \\
\hline 3 & -1 & 1 & 60 & 40 & $60.38 \mathrm{~d}, \mathrm{e}$ & $-6.43 \mathrm{~g}$ & $6.83 \mathrm{f}$ & $8.85 \mathrm{f}, \mathrm{g}$ & $16.69 \mathrm{c}-\mathrm{e}$ \\
\hline 4 & 0 & -1.41 & 65 & 15.86 & $58.06 \mathrm{i}$ & $-6.61 e, f$ & $6.46 \mathrm{~g}, \mathrm{~h}$ & $9.00 \mathrm{~g}$ & $16.18 d-f$ \\
\hline 5 & 0 & 0 & 65 & 30 & $60.90 \mathrm{c}$ & $-6.41 \mathrm{~g}$ & $6.90 \mathrm{e}, \mathrm{f}$ & $8.83 \mathrm{f}, \mathrm{g}$ & $17.10 \mathrm{c}$ \\
\hline 6 & 0 & 0 & 65 & 30 & $60.94 \mathrm{c}$ & $-6.62 \mathrm{e}, \mathrm{f}$ & 7.19 e & $8.48 \mathrm{e}$ & $16.83 \mathrm{c}, \mathrm{d}$ \\
\hline 7 & 0 & 0 & 65 & 30 & 56.311 & $-6.66 \mathrm{e}$ & $6.22 \mathrm{~h}$ & $9.06 \mathrm{~g}$ & $15.31 \mathrm{~g}-\mathrm{i}$ \\
\hline 8 & 0 & 0 & 65 & 30 & $59.38 \mathrm{~g}$ & $-6.56 e, f$ & $6.77 \mathrm{f}, \mathrm{g}$ & $8.79 \mathrm{f}, \mathrm{g}$ & $16.41 \mathrm{c}-\mathrm{f}$ \\
\hline 9 & 0 & 0 & 65 & 30 & $60.16 \mathrm{e}$ & $-6.61 e, f$ & $6.98 \mathrm{e}, \mathrm{f}$ & $8.92 \mathrm{f}, \mathrm{g}$ & $16.75 c-e$ \\
\hline 10 & 0 & 1.41 & 65 & 44.14 & $61.19 b$ & $-6.02 i$ & $7.07 \mathrm{e}, \mathrm{f}$ & $8.66 \mathrm{e}, \mathrm{f}$ & $15.16 \mathrm{~h}, \mathrm{i}$ \\
\hline 11 & 1 & -1 & 70 & 20 & $58.47 \mathrm{~h}$ & $-6.52 \mathrm{f}, \mathrm{g}$ & $7.93 \mathrm{c}, \mathrm{d}$ & $7.38 \mathrm{~d}$ & $15.70 \mathrm{f}-\mathrm{h}$ \\
\hline 12 & 1 & 1 & 70 & 40 & $60.49 \mathrm{~d}$ & $-7.09 \mathrm{~b}$ & $8.18 b, c$ & $7.40 \mathrm{~d}$ & $14.78 \mathrm{i}$ \\
\hline 13 & 1.41 & 0 & 72.07 & 30 & $59.69 \mathrm{f}$ & $-6.97 c$ & $8.33 \mathrm{~b}$ & $7.17 \mathrm{c}, \mathrm{d}$ & $15.90 \mathrm{f}-\mathrm{h}$ \\
\hline LSD (99\% & & & & & 0.229 & 0.123 & 0.355 & 0.292 & 0.753 \\
\hline \multicolumn{10}{|c|}{ Frozen/thawed mashed potatoes } \\
\hline Frozen/th & red con & & & & $64.99 \mathrm{a}$ & $-6.20 a-c$ & $12.66 \mathrm{a}$ & $5.13 \mathrm{a}$ & $20.48 \mathrm{a}$ \\
\hline \multicolumn{5}{|c|}{ Frozen/thawed control2** } & $63.30 \mathrm{~b}, \mathrm{c}$ & $-7.23 d$ & $12.89 \mathrm{a}$ & $4.91 \mathrm{a}$ & $19.70 \mathrm{a}$ \\
\hline 1 & -1.41 & 0 & 57.93 & 30 & $59.95 \mathrm{f}, \mathrm{g}$ & $-6.11 a, b$ & $8.06 \mathrm{c}-\mathrm{e}$ & $7.44 \mathrm{~b}, \mathrm{c}$ & $16.87 \mathrm{~d}, \mathrm{e}$ \\
\hline 2 & -1 & -1 & 60 & 20 & $60.22 \mathrm{f}$ & $-6.21 a-c$ & $8.81 b, c$ & $6.83 \mathrm{~b}$ & $17.81 \mathrm{~b}$ \\
\hline 3 & -1 & 1 & 60 & 40 & $63.09 c, d$ & $-6.15 a, b$ & $7.51 \mathrm{e}$ & $8.40 \mathrm{~d}$ & $16.99 \mathrm{c}-\mathrm{e}$ \\
\hline 4 & 0 & -1.41 & 65 & 15.86 & $60.09 \mathrm{f}, \mathrm{g}$ & $-6.39 a-c$ & $7.35 \mathrm{e}$ & $8.18 c, d$ & $16.40 \mathrm{e}$ \\
\hline 5 & 0 & 0 & 65 & 30 & $62.68 \mathrm{~d}$ & $-6.18 a-c$ & $7.56 \mathrm{e}$ & $8.29 \mathrm{~d}$ & 17.74 b, c \\
\hline 6 & 0 & 0 & 65 & 30 & $63.92 \mathrm{~b}$ & $-6.09 a, b$ & 8.15 b-e & $7.85 \mathrm{c}, \mathrm{d}$ & $16.72 \mathrm{~d}, \mathrm{e}$ \\
\hline 7 & 0 & 0 & 65 & 30 & $63.30 \mathrm{~b}, \mathrm{c}$ & $-6.13 a, b$ & $7.85 \mathrm{~d}, \mathrm{e}$ & $8.07 \mathrm{c}, \mathrm{d}$ & $16.28 \mathrm{e}$ \\
\hline 8 & 0 & 0 & 65 & 30 & $63.14 \mathrm{c}, \mathrm{d}$ & $-6.15 a, b$ & $7.70 \mathrm{e}$ & $8.18 c, d$ & $16.91 \mathrm{~d}, \mathrm{e}$ \\
\hline 9 & 0 & 0 & 65 & 30 & $63.61 \mathrm{~b}, \mathrm{c}$ & $-6.11 \mathrm{a}, \mathrm{b}$ & $8.00 \mathrm{c}-\mathrm{e}$ & $7.96 \mathrm{c}, \mathrm{d}$ & $17.33 b-d$ \\
\hline 10 & 0 & 1.41 & 65 & 44.14 & $62.60 \mathrm{~d}$ & $-6.10 a, b$ & $7.50 \mathrm{e}$ & $8.35 d$ & 16.32 e \\
\hline 11 & 1 & -1 & 70 & 20 & $59.58 \mathrm{~g}$ & $-6.51 b, c$ & $8.02 c-e$ & $7.43 \mathrm{~b}, \mathrm{c}$ & $16.72 \mathrm{~d}, \mathrm{e}$ \\
\hline 12 & 1 & 1 & 70 & 40 & $63.55 b, c$ & $-5.86 a$ & $8.59 b-d$ & $7.40 \mathrm{~b}, \mathrm{c}$ & $15.31 \mathrm{f}$ \\
\hline 13 & 1.41 & 0 & 72.07 & 30 & $61.20 \mathrm{e}$ & $-6.75 c, d$ & 8.92 b & $6.86 \mathrm{~b}$ & $16.79 \mathrm{~d}, \mathrm{e}$ \\
\hline \multicolumn{5}{|c|}{ LSD (99\%) } & 0.613 & 0.576 & 0.816 & 0.814 & 0.786 \\
\hline
\end{tabular}

Different letters in the same column indicate significant differences $P<0.01$. LSD, least significant difference.

*Mashed potatoes made without blanching.

*Mashed potatoes made without blanching and with added starch.

Values are given as mean score values of six determinations. 
Table 2 Textural and firmness parameters for the fresh and frozen/thawed mashed potatoes with the different blanching combinations, and controls

\begin{tabular}{|c|c|c|c|c|c|c|c|c|c|c|}
\hline Design point & $\begin{array}{l}\text { Hardness } \\
\text { (N) }\end{array}$ & $\begin{array}{l}\text { Adhesiveness } \\
\text { (N s) }\end{array}$ & Springiness & Cohesiveness & $\begin{array}{l}\text { Gumminess } \\
\text { (N) }\end{array}$ & $\begin{array}{l}\text { Firmness } \\
\text { (N) }\end{array}$ & $\begin{array}{l}\text { Area } \\
(\mathrm{N} \text { s) }\end{array}$ & $\begin{array}{l}\text { Firmness/ } \\
\text { product } \mathrm{g} \\
\left(\mathrm{N} \mathrm{g}^{-1}\right)\end{array}$ & $\begin{array}{l}\text { Area/disp vol } \\
\left(\mathrm{N} \mathrm{s} \mathrm{mm}^{-3}\right)\end{array}$ & $\begin{array}{l}\text { Average force } \\
\text { (N) }\end{array}$ \\
\hline \multicolumn{11}{|l|}{ Fresh mashed potatoes } \\
\hline Fresh control $1^{*}$ & $2.059 \mathrm{a}$ & $-2.498 a-c$ & $0.758 \mathrm{~b}, \mathrm{c}$ & $0.529 \mathrm{a}$ & $1.085 \mathrm{~d}, \mathrm{e}$ & $2.005 b-d$ & $2.085 c-g$ & $0.282 b-d$ & $0.277 \mathrm{E}-03 \mathrm{~b}-\mathrm{e}$ & $0.270 c-f$ \\
\hline Fresh control2** & $1.003 \mathrm{~d}, \mathrm{e}$ & $-1.899 \mathrm{c}, \mathrm{d}$ & $0.823 \mathrm{c}$ & $0.855 \mathrm{~b}$ & $0.858 \mathrm{~b}$ & $2.412 \mathrm{~d}-\mathrm{f}$ & $2.251 \mathrm{f}-\mathrm{h}$ & $0.343 \mathrm{~b}-\mathrm{e}$ & $0.300 \mathrm{E}-03 \mathrm{c}-\mathrm{e}$ & $0.292 \mathrm{e}-\mathrm{g}$ \\
\hline 1 & $0.508 f$ & $-1.132 \mathrm{e}$ & $0.587 \mathrm{a}$ & $1.059 \mathrm{~d}$ & $0.536 \mathrm{a}$ & $1.344 \mathrm{a}$ & $1.123 \mathrm{a}$ & $0.189 a$ & $0.149 \mathrm{E}-03 \mathrm{a}$ & $0.146 \mathrm{a}$ \\
\hline 2 & $0.858 \mathrm{e}$ & $-1.899 c, d$ & $0.822 \mathrm{c}$ & $1.064 \mathrm{~d}$ & $0.913 b, c$ & $1.851 \mathrm{~b}$ & $1.622 \mathrm{~b}$ & $0.264 a, b$ & $0.216 \mathrm{E}-03 \mathrm{a}, \mathrm{b}$ & $0.210 \mathrm{~b}$ \\
\hline 3 & $0.931 \mathrm{e}$ & $-2.013 b-d$ & $0.815 \mathrm{c}$ & $0.966 \mathrm{~b}-\mathrm{d}$ & $0.897 b, c$ & $1.978 \mathrm{~b}-\mathrm{d}$ & $1.713 b, c$ & $0.281 \mathrm{~b}-\mathrm{d}$ & $0.228 \mathrm{E}-03 \mathrm{a}-\mathrm{c}$ & $0.222 b, c$ \\
\hline 4 & $0.899 \mathrm{e}$ & $-1.850 d$ & $0.769 \mathrm{~b}, \mathrm{c}$ & $1.035 \mathrm{~d}$ & $0.928 \mathrm{~b}, \mathrm{c}$ & $1.869 \mathrm{~b}$ & $1.720 \mathrm{~b}-\mathrm{d}$ & $0.263 a, b$ & $0.229 \mathrm{E}-03 \mathrm{a}-\mathrm{c}$ & $0.223 b, c$ \\
\hline 5 & $1.389 \mathrm{~b}$ & $-2.518 a-c$ & $0.867 \mathrm{c}$ & $0.879 b, c$ & $1.218 \mathrm{e}-\mathrm{g}$ & $2.836 \mathrm{f}$ & $2.579 \mathrm{~h}$ & $0.399 \mathrm{e}$ & $0.343 \mathrm{E}-03 \mathrm{e}$ & $0.334 \mathrm{~g}$ \\
\hline 6 & $1.247 \mathrm{~b}, \mathrm{c}$ & $-2.742 \mathrm{a}$ & $0.815 \mathrm{c}$ & $1.006 \mathrm{c}, \mathrm{d}$ & $1.254 \mathrm{f}, \mathrm{g}$ & $2.546 \mathrm{e}, \mathrm{f}$ & $2.408 \mathrm{~g}, \mathrm{~h}$ & $0.364 \mathrm{c}-\mathrm{e}$ & $0.320 \mathrm{E}-03 \mathrm{~d}, \mathrm{e}$ & $0.312 \mathrm{f}, \mathrm{g}$ \\
\hline 7 & $1.028 \mathrm{~d}, \mathrm{e}$ & $-1.937 \mathrm{c}, \mathrm{d}$ & $0.790 \mathrm{~b}, \mathrm{c}$ & $1.014 \mathrm{c}, \mathrm{d}$ & $1.041 \mathrm{c}, \mathrm{d}$ & $1.928 \mathrm{~b}, \mathrm{c}$ & $1.801 \mathrm{~b}-\mathrm{e}$ & $0.272 \mathrm{a}, \mathrm{b}$ & $0.240 \mathrm{E}-03 \mathrm{~b}-\mathrm{d}$ & $0.233 \mathrm{~b}-\mathrm{d}$ \\
\hline 8 & $1.221 \mathrm{~b}, \mathrm{c}$ & $-2.399 a-d$ & $0.824 \mathrm{c}$ & $0.966 \mathrm{~b}-\mathrm{d}$ & $1.171 \mathrm{~d}-\mathrm{f}$ & $2.367 \mathrm{c}-\mathrm{e}$ & $2.200 \mathrm{e}-\mathrm{h}$ & $0.335 \mathrm{~b}-\mathrm{e}$ & $0.343 \mathrm{E}-03 \mathrm{e}$ & $0.285 \mathrm{~d}-\mathrm{g}$ \\
\hline 9 & $1.305 \mathrm{~b}, \mathrm{c}$ & $-2.570 a, b$ & $0.845 \mathrm{c}$ & $0.990 \mathrm{~b}-\mathrm{d}$ & $1.212 \mathrm{e}-\mathrm{g}$ & $2.601 \mathrm{e}, \mathrm{f}$ & $2.389 \mathrm{~g}, \mathrm{~h}$ & $0.367 \mathrm{~d}, \mathrm{e}$ & $0.318 \mathrm{E}-03 \mathrm{~d}, \mathrm{e}$ & $0.310 \mathrm{f}, \mathrm{g}$ \\
\hline 10 & $0.922 \mathrm{e}$ & $-1.778 d$ & $0.672 \mathrm{a}, \mathrm{b}$ & $0.982 \mathrm{~b}-\mathrm{d}$ & $0.891 \mathrm{~b}, \mathrm{c}$ & $2.245 \mathrm{~b}-\mathrm{e}$ & $1.908 b-f$ & $0.321 \mathrm{~b}-\mathrm{e}$ & $0.254 \mathrm{E}-03 \mathrm{~b}-\mathrm{d}$ & $0.248 b-e$ \\
\hline 11 & $1.132 \mathrm{c}, \mathrm{d}$ & $-2.340 a-d$ & $0.863 \mathrm{c}$ & $1.051 \mathrm{~d}$ & $1.189 \mathrm{~d}-\mathrm{f}$ & $2.295 b-e$ & $2.146 \mathrm{e}-\mathrm{g}$ & $0.328 b-e$ & $0.286 \mathrm{E}-03 \mathrm{~b}-\mathrm{e}$ & $0.278 \mathrm{~d}-\mathrm{f}$ \\
\hline 12 & $1.202 \mathrm{c}$ & $-2.574 a, b$ & $0.870 \mathrm{c}$ & $1.085 \mathrm{~d}$ & $1.304 \mathrm{f}, \mathrm{g}$ & $1.940 \mathrm{~b}, \mathrm{c}$ & $1.882 b-f$ & $0.277 b, c$ & $0.250 \mathrm{E}-03 \mathrm{~b}-\mathrm{d}$ & $0.244 \mathrm{~b}-\mathrm{e}$ \\
\hline 13 & $1.300 \mathrm{~b}, \mathrm{c}$ & $-2.697 \mathrm{a}$ & $0.869 \mathrm{c}$ & $1.048 \mathrm{~d}$ & $1.360 \mathrm{~g}$ & $2.229 \mathrm{~b}-\mathrm{e}$ & $2.130 \mathrm{~d}-\mathrm{g}$ & $0.316 \mathrm{~b}-\mathrm{e}$ & $0.283 \mathrm{E}-03 \mathrm{~b}-\mathrm{e}$ & $0.276 \mathrm{~d}-\mathrm{f}$ \\
\hline LSD (99\%) & 0.175 & 0.629 & 0.123 & 0.143 & $0.155^{\circ}$ & 0.456 & 0.412 & 0.087 & 0.0001 & 0.052 \\
\hline \multicolumn{11}{|c|}{ Frozen/thawed mashed potatoes } \\
\hline Frozen/thawed control $1^{*}$ & $1.629 \mathrm{a}$ & $-3.371 a-c$ & $0.914 \mathrm{a}$ & $0.913 \mathrm{a}$ & $1.486 \mathrm{~d}, \mathrm{e}$ & $2.708 \mathrm{~b}-\mathrm{d}$ & $2.534 \mathrm{a}, \mathrm{b}$ & $0.383 a, b$ & $0.337 \mathrm{E}-03 \mathrm{a}, \mathrm{b}$ & $0.328 a, b$ \\
\hline Frozen/thawed control ${ }^{\star *}$ & $1.491 \mathrm{a}$ & $-3.266 a-d$ & $0.936 \mathrm{a}$ & $0.912 \mathrm{a}$ & $1.358 \mathrm{c}, \mathrm{d}$ & $3.108 \mathrm{a}$ & $2.848 \mathrm{a}$ & $0.442 \mathrm{a}$ & $0.379 \mathrm{E}-03 \mathrm{a}$ & $0.369 \mathrm{a}$ \\
\hline 1 & $0.818 \mathrm{~d}, \mathrm{e}$ & $-1.964 \mathrm{f}, \mathrm{g}$ & $0.824 \mathrm{c}$ & $1.182 \mathrm{~g}$ & $0.967 \mathrm{~b}$ & $1.821 \mathrm{e}, \mathrm{f}$ & $1.611 \mathrm{~d}$ & $0.259 \mathrm{c}, \mathrm{d}$ & $0.214 \mathrm{E}-03 \mathrm{c}, \mathrm{d}$ & $0.209 \mathrm{c}, \mathrm{d}$ \\
\hline 2 & $1.174 \mathrm{c}$ & $-2.784 c-e$ & $0.913 \mathrm{a}$ & $1.079 \mathrm{c}-\mathrm{g}$ & $1.264 \mathrm{c}$ & $2.812 \mathrm{a}-\mathrm{d}$ & $2.533 \mathrm{a}, \mathrm{b}$ & $0.401 \mathrm{a}$ & $0.337 \mathrm{E}-03 \mathrm{a}, \mathrm{b}$ & $0.328 a, b$ \\
\hline 3 & $1.229 \mathrm{c}$ & $-2.899 b-d$ & $0.910 \mathrm{a}$ & $1.112 \mathrm{~d}-\mathrm{g}$ & $1.363 \mathrm{c}, \mathrm{d}$ & $3.072 \mathrm{a}, \mathrm{b}$ & $2.723 a, b$ & $0.439 a$ & $0.362 \mathrm{E}-03 \mathrm{a}$ & $0.353 \mathrm{a}$ \\
\hline 4 & $0.877 \mathrm{~d}$ & $-2.091 \mathrm{e}-\mathrm{g}$ & $0.837 \mathrm{c}$ & $1.140 \mathrm{e}-\mathrm{g}$ & $0.998 \mathrm{~b}$ & $1.684 \mathrm{f}$ & $1.615 d$ & $0.241 \mathrm{c}, \mathrm{d}$ & $0.215 E-03 c, d$ & $0.210 \mathrm{c}, \mathrm{d}$ \\
\hline 5 & $1.537 \mathrm{a}$ & $-3.780 a$ & $0.932 \mathrm{a}$ & $1.020 \mathrm{a}-\mathrm{d}$ & $1.567 \mathrm{e}, \mathrm{f}$ & $2.788 \mathrm{a}-\mathrm{d}$ & $2.598 \mathrm{a}, \mathrm{b}$ & $0.398 \mathrm{a}$ & $0.346 \mathrm{E}-03 \mathrm{a}, \mathrm{b}$ & $0.337 \mathrm{a}, \mathrm{b}$ \\
\hline 6 & $1.563 \mathrm{a}$ & $-3.861 \mathrm{a}$ & $0.925 \mathrm{a}$ & $1.021 \mathrm{a}-\mathrm{e}$ & $1.588 \mathrm{e}, \mathrm{f}$ & $2.846 \mathrm{a}-\mathrm{d}$ & $2.771 \mathrm{a}, \mathrm{b}$ & $0.407 \mathrm{a}$ & $0.369 \mathrm{E}-03 \mathrm{a}$ & $0.359 \mathrm{a}$ \\
\hline 7 & $1.306 \mathrm{~b}, \mathrm{c}$ & $-2.946 b-d$ & $0.891 \mathrm{a}, \mathrm{b}$ & $0.970 \mathrm{a}-\mathrm{c}$ & $1.263 \mathrm{c}$ & $2.160 \mathrm{e}$ & $2.127 \mathrm{c}$ & $0.307 \mathrm{~b}, \mathrm{c}$ & $0.283 \mathrm{E}-03 \mathrm{~b}, \mathrm{c}$ & $0.276 \mathrm{~b}, \mathrm{c}$ \\
\hline 8 & $1.469 a, b$ & $-3.529 a-c$ & $0.916 \mathrm{a}$ & $1.004 \mathrm{a}-\mathrm{d}$ & $1.451 \mathrm{~d}, \mathrm{e}$ & $2.598 \mathrm{~d}$ & $2.499 \mathrm{~b}$ & $0.371 \mathrm{a}, \mathrm{b}$ & $0.333 \mathrm{E}-03 \mathrm{a}, \mathrm{b}$ & $0.324 a, b$ \\
\hline 9 & $1.516 \mathrm{a}$ & $-3.695 a$ & $0.924 \mathrm{a}$ & $1.012 \mathrm{a}-\mathrm{d}$ & $1.509 \mathrm{~d}-\mathrm{f}$ & $2.693 \mathrm{c}, \mathrm{d}$ & $2.635 a, b$ & $0.389 a$ & $0.351 \mathrm{E}-03 \mathrm{a}, \mathrm{b}$ & $0.341 \mathrm{a}, \mathrm{b}$ \\
\hline 10 & $0.656 \mathrm{e}$ & $-1.512 \mathrm{~g}$ & $0.652 \mathrm{~d}$ & $1.147 \mathrm{f}, \mathrm{g}$ & $0.750 \mathrm{a}$ & $1.285 \mathrm{~g}$ & $1.191 \mathrm{e}$ & $0.184 \mathrm{~d}$ & $0.158 \mathrm{E}-03 d$ & $0.154 \mathrm{~d}$ \\
\hline 11 & $1.585 \mathrm{a}$ & $-3.597 a-d$ & $0.908 \mathrm{a}, \mathrm{b}$ & $1.046 b-f$ & $1.657 f$ & $3.020 \mathrm{a}-\mathrm{c}$ & $2.779 a, b$ & $0.431 \mathrm{a}$ & $0.370 \mathrm{E}-03 \mathrm{a}$ & $0.360 \mathrm{a}$ \\
\hline 12 & $1.525 \mathrm{a}$ & $-3.191 a-d$ & $0.907 \mathrm{a}, \mathrm{b}$ & $0.929 a, b$ & $1.409 \mathrm{c}, \mathrm{d}$ & $2.633 \mathrm{~d}$ & $2.671 \mathrm{a}, \mathrm{b}$ & $0.376 \mathrm{a}, \mathrm{b}$ & $0.356 \mathrm{E}-03 \mathrm{a}, \mathrm{b}$ & $0.346 \mathrm{a}, \mathrm{b}$ \\
\hline 13 & $1.136 \mathrm{c}$ & $-2.557 d-f$ & $0.861 \mathrm{~b}, \mathrm{c}$ & $0.968 a-c$ & $1.100 \mathrm{~b}$ & $1.650 \mathrm{f}, \mathrm{g}$ & $1.596 \mathrm{~d}$ & $0.233 \mathrm{c}, \mathrm{d}$ & $0.212 E-03 c, d$ & $0.207 \mathrm{c}, \mathrm{d}$ \\
\hline LSD (99\%) & 0.180 & 0.745 & 0.049 & 0.120 & 0.154 & 0.373 & 0.328 & 0.079 & 0.0001 & 0.070 \\
\hline
\end{tabular}

Different letters in the same column indicate significant differences $P<0.01$. LSD, least significant difference.

Different letters in the same column indicate
*Mashed potatoes made without blanching.

**Mashed potatoes made without blanching and with added starch

Values are given as mean score values of eight determinations. 
Table 3 Oscillatory parameters for the fresh and frozen/thawed mashed potatoes with the different blanching combinations, and controls

\begin{tabular}{|c|c|c|c|c|c|}
\hline Design point & $\begin{array}{l}\text { Phase angle } \\
\delta \square\left({ }^{\circ}\right)\end{array}$ & $\begin{array}{l}\text { Complex } \\
\text { modulus } \\
\mathrm{G}^{*}(\mathrm{~Pa})\end{array}$ & 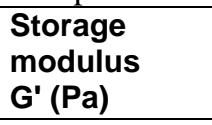 & $\begin{array}{l}\text { Loss } \\
\text { modulus } \\
\text { G" (Pa) }\end{array}$ & $\begin{array}{l}\text { Complex } \\
\text { viscosity } \\
\eta^{\star}(\mathrm{Pas})\end{array}$ \\
\hline \multicolumn{6}{|l|}{ Fresh mashed potatoes } \\
\hline Fresh control1* & $11.567 \mathrm{a}, \mathrm{b}$ & $4856.900 \mathrm{f}, \mathrm{g}$ & $4758.567 \mathrm{f}, \mathrm{g}$ & 972.273 c-e & $4576.533 \mathrm{f}-\mathrm{h}$ \\
\hline Fresh control2** & $14.033 \mathrm{~b}, \mathrm{c}$ & $3092.500 \mathrm{c}$ & $3000.233 \mathrm{c}$ & $749.160 \mathrm{~b}$ & $2918.067 \mathrm{c}, \mathrm{d}$ \\
\hline 1 & 23.833 e & $976.543 \mathrm{a}$ & 891.690 a & 396.257 a & 919.997 a \\
\hline 2 & $15.500 \mathrm{c}, \mathrm{d}$ & $3089.100 \mathrm{c}$ & 2975.733 c & 827.947 b, c & $2902.633 \mathrm{c}, \mathrm{d}$ \\
\hline 3 & $15.467 \mathrm{c}, \mathrm{d}$ & 2750.633 c & 2650.933 c & $733.567 \mathrm{~b}$ & 2594.333 c \\
\hline 4 & $13.500 \mathrm{a}-\mathrm{c}$ & $3675.267 d$ & $3573.100 \mathrm{~d}$ & 855.710 b-d & $3474.467 \mathrm{~d}, \mathrm{e}$ \\
\hline 5 & $13.233 \mathrm{a}-\mathrm{c}$ & 4244.133 e & 4130.233 e & 967.990 c-e & 4010.200 e, f \\
\hline 6 & $10.700 \mathrm{a}$ & $5746.700 \mathrm{~h}$ & $5647.067 \mathrm{~h}$ & $1064.733 \mathrm{e}$ & $5417.867 \mathrm{i}$ \\
\hline 7 & $12.133 a, b$ & 4525.233 e, f & 4424.733 e, f & $946.053 \mathrm{c}-\mathrm{e}$ & $4279.633 \mathrm{f}, \mathrm{g}$ \\
\hline 8 & $12.022 \mathrm{a}, \mathrm{b}$ & $4838.688 \mathrm{f}, \mathrm{g}$ & $4734.011 \mathrm{f}, \mathrm{g}$ & $992.925 \mathrm{~d}, \mathrm{e}$ & $4569.233 \mathrm{f}-\mathrm{h}$ \\
\hline 9 & $12.627 \mathrm{a}-\mathrm{c}$ & $5292.694 \mathrm{~g}, \mathrm{~h}$ & $5190.539 \mathrm{~g}, \mathrm{~h}$ & 1028.829 e & 4993.550 h, i \\
\hline 10 & $17.400 \mathrm{~d}$ & $1631.800 \mathrm{~b}$ & $1558.067 \mathrm{~b}$ & $480.537 \mathrm{a}$ & $1546.500 \mathrm{~b}$ \\
\hline 11 & $12.133 a, b$ & $4736.800 \mathrm{f}$ & $4631.100 \mathrm{f}$ & $994.423 \mathrm{~d}, \mathrm{e}$ & $4470.933 \mathrm{f}-\mathrm{h}$ \\
\hline 12 & $11.400 \mathrm{a}, \mathrm{b}$ & $4912.833 \mathrm{f}, \mathrm{g}$ & $4815.867 \mathrm{f}, \mathrm{g}$ & 970.700 c-e & $4638.767 \mathrm{~g}, \mathrm{~h}$ \\
\hline 13 & $12.333 \mathrm{a}, \mathrm{b}$ & $4920.167 \mathrm{f}, \mathrm{g}$ & $4806.700 \mathrm{f}, \mathrm{g}$ & 1049.163 e & $4643.667 \mathrm{~g}, \mathrm{~h}$ \\
\hline \multirow{2}{*}{\multicolumn{6}{|c|}{ Frozen/thawed mashed potatoes }} \\
\hline & & & & & \\
\hline Frozen/thawed control1* & $12.900 \mathrm{~b}, \mathrm{c}$ & 3900.667 b-d & $3801.133 b-d$ & 872.353 a & $3678.000 b-d$ \\
\hline Frozen/thawed control2 ${ }^{* *}$ & $12.900 \mathrm{~b}, \mathrm{c}$ & $2785.867 \mathrm{f}$ & $2715.600 \mathrm{f}$ & $621.657 \mathrm{c}$ & $2622.000 \mathrm{e}$ \\
\hline 1 & $15.000 \mathrm{a}$ & $1436.133 \mathrm{~h}$ & $1387.300 \mathrm{~h}$ & $371.303 \mathrm{e}$ & $1351.867 \mathrm{~g}$ \\
\hline 2 & $11.933 \mathrm{c}, \mathrm{d}$ & $2805.333 \mathrm{f}$ & $2744.467 f$ & $580.950 \mathrm{c}, \mathrm{d}$ & $2645.033 \mathrm{e}$ \\
\hline 3 & $11.800 \mathrm{c}-\mathrm{e}$ & $2696.033 \mathrm{f}$ & $2638.700 \mathrm{f}$ & $551.487 \mathrm{c}, \mathrm{d}$ & 2541.867 e \\
\hline 4 & $10.600 \mathrm{~d}-\mathrm{g}$ & 3116.433 e, f & $3063.467 \mathrm{e}, \mathrm{f}$ & $571.660 \mathrm{c}, \mathrm{d}$ & 2935.633 e \\
\hline 5 & $11.633 c-f$ & $4368.200 a, b$ & $4278.533 a, b$ & $879.900 \mathrm{a}$ & $4113.633 a, b$ \\
\hline 6 & $10.400 \mathrm{e}-\mathrm{g}$ & $4629.067 \mathrm{a}$ & $4552.633 \mathrm{a}$ & $837.503 \mathrm{a}$ & $4355.933 \mathrm{a}$ \\
\hline 7 & $10.333 \mathrm{f}, \mathrm{g}$ & $3682.800 \mathrm{~d}$ & $3622.700 \mathrm{c}, \mathrm{d}$ & $660.673 \mathrm{~b}, \mathrm{c}$ & $3475.167 \mathrm{~d}$ \\
\hline 8 & $10.789 \mathrm{~d}-\mathrm{g}$ & $4226.689 a, b$ & 4151.289 a-c & $792.692 \mathrm{a}, \mathrm{b}$ & $3981.578 \mathrm{a}-\mathrm{c}$ \\
\hline 9 & $10.561 \mathrm{~d}-\mathrm{g}$ & $4427.878 a, b$ & $4351.961 \mathrm{a}$ & $836.296 \mathrm{a}$ & $4168.755 \mathrm{a}$ \\
\hline 10 & $14.000 \mathrm{a}, \mathrm{b}$ & $2012.333 \mathrm{~g}$ & $1952.400 \mathrm{~g}$ & $487.203 \mathrm{~d}, \mathrm{e}$ & $1899.367 \mathrm{f}$ \\
\hline 11 & $11.433 \mathrm{~d}-\mathrm{f}$ & $4432.767 \mathrm{a}, \mathrm{b}$ & $4344.833 \mathrm{a}$ & $878.447 \mathrm{a}$ & $4178.533 \mathrm{a}$ \\
\hline 12 & $9.767 \mathrm{~g}$ & $3769.867 \mathrm{c}, \mathrm{d}$ & $3715.133 \mathrm{c}, \mathrm{d}$ & $639.957 \mathrm{c}$ & $3569.000 \mathrm{c}, \mathrm{d}$ \\
\hline 13 & $10.733 \mathrm{~d}-\mathrm{g}$ & $3647.100 \mathrm{~d}, \mathrm{e}$ & $3583.300 \mathrm{~d}, \mathrm{e}$ & 677.923 b, c & $3440.100 \mathrm{~d}$ \\
\hline LSD (99\%) & 1.426 & 541.577 & 532.172 & 132.399 & 461.332 \\
\hline
\end{tabular}

Different letters in the same column indicate significant differences $P<0.01$.

LSD, least significant difference.

*Mashed potatoes made without blanching.

${ }^{* *}$ Mashed potatoes made without blanching and with added starch.

Values are given as mean score values of six determinations. 
Table 4 Sensory attributes perceived before and at the time of putting the sample in the mouth, and at the time of preparing the sample for swallowing, for fresh and frozen/thawed mashed potatoes with the different blanching combinations, and controls

\begin{tabular}{|c|c|c|c|c|c|c|c|c|c|c|}
\hline \multirow{2}{*}{$\begin{array}{l}\text { Sensory attributes } \\
\text { Design point } \\
\end{array}$} & \multicolumn{2}{|c|}{$\begin{array}{l}\text { Perceived before putting } \\
\text { the sample in the mouth }\end{array}$} & \multicolumn{5}{|c|}{ Perceived at the time of putting the sample in the mouth } & \multicolumn{3}{|c|}{$\begin{array}{l}\text { Perceived at the time of preparing the sample } \\
\text { for swallowing }\end{array}$} \\
\hline & Granularity & Moisture & Adhesiveness & Denseness & Homogeneity & Moisture & Firmness & Cohesiveness & Adhesiveness & Fibrousness \\
\hline \multicolumn{11}{|l|}{ Fresh mashed potatoes } \\
\hline Fresh Control1* & $1.62 \mathrm{a}$ & $5.52 \mathrm{~b}$ & 5.05 b, c & $6.37 \mathrm{~d}, \mathrm{e}$ & $9.00 \mathrm{a}$ & $5.22 b-d$ & $6.67 \mathrm{c}-\mathrm{f}$ & $5.85 b-d$ & $5.47 b-e$ & $1.37 \mathrm{a}$ \\
\hline Fresh control2** & $1.70 \mathrm{a}, \mathrm{b}$ & $5.02 b-d$ & $6.22 \mathrm{~d}, \mathrm{e}$ & $6.00 \mathrm{c}, \mathrm{d}$ & $8.65 a, b$ & $5.32 \mathrm{~b}, \mathrm{c}$ & $6.15 \mathrm{c}, \mathrm{d}$ & $5.35 b, c$ & $4.60 \mathrm{~b}$ & $1.35 \mathrm{a}$ \\
\hline 1 & $1.70 \mathrm{a}, \mathrm{b}$ & $7.97 \mathrm{a}$ & $3.10 \mathrm{a}$ & $2.92 \mathrm{a}$ & $7.77 \mathrm{~b}$ & $7.87 \mathrm{a}$ & $2.65 \mathrm{a}$ & $2.90 \mathrm{a}$ & $3.17 \mathrm{a}$ & $2.52 \mathrm{c}, \mathrm{d}$ \\
\hline 2 & $2.27 a-c$ & $4.97 \mathrm{~b}-\mathrm{d}$ & $7.42 \mathrm{f}, \mathrm{g}$ & $4.67 \mathrm{~b}$ & $8.15 a, b$ & $4.55 \mathrm{~d}-\mathrm{f}$ & $5.05 \mathrm{~b}$ & $6.35 c-e$ & $8.32 \mathrm{~h}$ & $2.20 a-d$ \\
\hline 3 & $2.85 \mathrm{c}, \mathrm{d}$ & $5.52 \mathrm{~b}$ & $6.62 \mathrm{~d}-\mathrm{f}$ & $5.92 \mathrm{c}, \mathrm{d}$ & $8.15 a, b$ & $4.75 c-e$ & $6.70 \mathrm{~d}-\mathrm{f}$ & $5.67 b, c$ & $6.97 \mathrm{f}, \mathrm{g}$ & $3.02 \mathrm{c}$ \\
\hline 4 & $2.17 a-c$ & $5.47 \mathrm{~b}$ & $5.70 b-d$ & $5.75 c$ & $8.62 a, b$ & $5.32 b, c$ & $6.12 \mathrm{c}, \mathrm{d}$ & $5.42 b, c$ & $5.90 c-f$ & $2.25 a-d$ \\
\hline 5 & $2.32 \mathrm{~b}, \mathrm{c}$ & $3.80 \mathrm{e}$ & $6.90 \mathrm{e}-\mathrm{g}$ & $7.85 f$ & $8.47 a, b$ & $3.87 \mathrm{f}, \mathrm{g}$ & $7.72 \mathrm{f}, \mathrm{g}$ & $7.35 \mathrm{e}$ & $6.97 \mathrm{f}, \mathrm{g}$ & $2.60 \mathrm{c}, \mathrm{d}$ \\
\hline 6 & $2.15 a, b$ & $5.55 b$ & $5.87 \mathrm{c}, \mathrm{d}$ & $7.17 \mathrm{e}, \mathrm{f}$ & $8.57 \mathrm{a}, \mathrm{b}$ & $5.37 \mathrm{~b}, \mathrm{c}$ & $7.82 \mathrm{~g}$ & $5.70 \mathrm{~b}, \mathrm{c}$ & $6.12 \mathrm{c}-\mathrm{f}$ & $2.32 a-d$ \\
\hline 7 & $1.82 \mathrm{a}, \mathrm{b}$ & $5.32 \mathrm{~b}$ & $4.82 \mathrm{~b}$ & $5.62 \mathrm{~b}, \mathrm{c}$ & $8.20 \mathrm{a}, \mathrm{b}$ & $5.67 \mathrm{~b}$ & $6.60 \mathrm{c}-\mathrm{e}$ & $6.07 \mathrm{~b}-\mathrm{d}$ & $5.10 \mathrm{~b}, \mathrm{c}$ & $2.10 \mathrm{a}-\mathrm{c}$ \\
\hline 8 & $2.10 a, b$ & $4.89 \mathrm{~b}-\mathrm{d}$ & $5.82 \mathrm{c}, \mathrm{d}$ & $6.88 \mathrm{~d}-\mathrm{f}$ & $8.41 \mathrm{a}, \mathrm{b}$ & $4.97 \mathrm{~b}-\mathrm{e}$ & $7.38 \mathrm{e}-\mathrm{g}$ & $6.37 \mathrm{c}-\mathrm{e}$ & $6.06 \mathrm{c}-\mathrm{f}$ & $2.33 b-d$ \\
\hline 9 & $2.21 \mathrm{a}-\mathrm{c}$ & $4.34 c-e$ & $6.38 \mathrm{~d}, \mathrm{e}$ & $7.36 \mathrm{e}, \mathrm{f}$ & $8.45 a, b$ & $4.42 \mathrm{e}-\mathrm{g}$ & $7.55 \mathrm{e}-\mathrm{g}$ & $6.86 \mathrm{~d}, \mathrm{e}$ & $6.52 \mathrm{e}-\mathrm{g}$ & $2.47 b-d$ \\
\hline 10 & $3.52 \mathrm{~d}$ & $5.35 \mathrm{~b}$ & $6.25 \mathrm{~d}, \mathrm{e}$ & $5.67 b, c$ & $6.57 \mathrm{c}$ & $2.90 \mathrm{~h}$ & $5.62 b, c$ & $5.55 b, c$ & $5.40 \mathrm{~b}-\mathrm{d}$ & $3.97 \mathrm{~d}$ \\
\hline 11 & $2.00 a, b$ & $5.42 \mathrm{~b}$ & $6.35 \mathrm{~d}, \mathrm{e}$ & $5.82 \mathrm{c}, \mathrm{d}$ & $8.57 \mathrm{a}, \mathrm{b}$ & $5.30 \mathrm{~b}, \mathrm{c}$ & $7.07 \mathrm{~d}-\mathrm{g}$ & $6.90 \mathrm{~d}, \mathrm{e}$ & $6.42 \mathrm{~d}-\mathrm{g}$ & $1.65 a, b$ \\
\hline 12 & $2.27 \mathrm{a}-\mathrm{c}$ & $4.05 \mathrm{~d}, \mathrm{e}$ & $7.60 \mathrm{~g}$ & $7.47 f$ & $8.27 \mathrm{a}, \mathrm{b}$ & $3.75 \mathrm{~g}$ & $7.82 \mathrm{~g}$ & $7.37 \mathrm{e}$ & $7.27 \mathrm{~g}, \mathrm{~h}$ & $2.32 \mathrm{a}-\mathrm{d}$ \\
\hline 13 & $1.77 \mathrm{a}, \mathrm{b}$ & $5.15 b, c$ & $5.80 \mathrm{c}, \mathrm{d}$ & $6.00 \mathrm{c}, \mathrm{d}$ & $8.92 a, b$ & $5.15 b-e$ & $6.27 \mathrm{c}, \mathrm{d}$ & $5.00 \mathrm{~b}$ & $4.57 \mathrm{~b}$ & $1.82 \mathrm{a}-\mathrm{c}$ \\
\hline LSD (95\%) & 0.69 & 0.98 & 0.93 & 1.06 & 0.92 & 0.74 & 1.07 & 1.14 & 1.12 & 0.87 \\
\hline \multicolumn{11}{|l|}{$\begin{array}{l}\text { Frozen/thawed mashed } \\
\text { potatoes }\end{array}$} \\
\hline Frozen/thawed control1* & $1.52 \mathrm{a}$ & $6.42 \mathrm{~b}$ & $7.35 \mathrm{a}-\mathrm{d}$ & $7.77 \mathrm{a}-\mathrm{c}$ & $8.60 a, b$ & $6.22 \mathrm{~b}$ & $7.80 \mathrm{~b}-\mathrm{e}$ & $6.22 \mathrm{~b}, \mathrm{c}$ & $6.22 \mathrm{c}-\mathrm{e}$ & $1.60 \mathrm{a}, \mathrm{b}$ \\
\hline Frozen/thawed control2** & $1.85 \mathrm{a}$ & $2.37 f$ & $8.07 \mathrm{a}$ & $8.15 a, b$ & $8.22 a, b$ & $2.50 \mathrm{f}, \mathrm{g}$ & $8.32 a-c$ & $7.77 \mathrm{a}$ & $7.37 \mathrm{a}-\mathrm{c}$ & $1.80 a, b$ \\
\hline 1 & $3.25 b, c$ & $3.37 e, f$ & $6.77 b-d$ & $6.97 \mathrm{c}$ & $8.17 \mathrm{a}, \mathrm{b}$ & $4.07 \mathrm{~d}, \mathrm{e}$ & $7.25 d-f$ & $6.37 \mathrm{a}-\mathrm{c}$ & $6.50 \mathrm{c}, \mathrm{d}$ & $2.30 \mathrm{a}-\mathrm{c}$ \\
\hline 2 & $3.27 b, c$ & $3.00 e, f$ & $8.55 \mathrm{a}$ & $7.52 \mathrm{a}-\mathrm{c}$ & $8.05 b$ & $3.15 \mathrm{e}, \mathrm{f}$ & $7.95 a-d$ & $7.12 \mathrm{a}-\mathrm{c}$ & $7.77 \mathrm{a}, \mathrm{b}$ & $2.27 \mathrm{a}-\mathrm{c}$ \\
\hline 3 & $6.32 \mathrm{f}$ & $2.60 \mathrm{f}$ & $7.92 \mathrm{a}, \mathrm{b}$ & $7.45 \mathrm{~b}, \mathrm{c}$ & $5.72 \mathrm{c}$ & $1.87 \mathrm{~g}$ & $7.47 \mathrm{c}-\mathrm{e}$ & $7.32 \mathrm{a}, \mathrm{b}$ & $7.42 \mathrm{a}-\mathrm{c}$ & $2.90 \mathrm{c}, \mathrm{d}$ \\
\hline 4 & $2.57 \mathrm{a}, \mathrm{b}$ & $4.82 \mathrm{c}, \mathrm{d}$ & $5.30 \mathrm{e}, \mathrm{f}$ & $5.65 d$ & $8.32 \mathrm{a}, \mathrm{b}$ & $4.10 \mathrm{~d}, \mathrm{e}$ & $6.55 \mathrm{f}, \mathrm{g}$ & $6.55 \mathrm{a}-\mathrm{c}$ & $6.90 \mathrm{~b}-\mathrm{d}$ & $2.27 \mathrm{a}-\mathrm{c}$ \\
\hline 5 & $5.40 \mathrm{e}, \mathrm{f}$ & $2.70 \mathrm{f}$ & $8.40 \mathrm{a}$ & $8.52 \mathrm{a}$ & $8.50 a, b$ & $3.15 e, f$ & $8.72 \mathrm{a}$ & $7.60 \mathrm{a}, \mathrm{b}$ & $8.42 \mathrm{a}$ & $2.10 \mathrm{a}-\mathrm{c}$ \\
\hline 6 & $4.77 \mathrm{~d}, \mathrm{e}$ & $3.37 \mathrm{e}, \mathrm{f}$ & $7.82 \mathrm{a}, \mathrm{b}$ & $7.80 \mathrm{a}-\mathrm{c}$ & $8.87 \mathrm{a}, \mathrm{b}$ & $3.60 \mathrm{e}, \mathrm{f}$ & $8.05 a-d$ & $6.92 \mathrm{a}-\mathrm{c}$ & 6.65 b-d & $2.20 \mathrm{a}-\mathrm{c}$ \\
\hline 7 & $4.02 \mathrm{c}, \mathrm{d}$ & $4.02 \mathrm{~d}, \mathrm{e}$ & $6.07 \mathrm{~d}-\mathrm{f}$ & $7.57 \mathrm{a}-\mathrm{c}$ & $8.95 a, b$ & $3.67 \mathrm{e}$ & $7.60 \mathrm{~b}-\mathrm{e}$ & $6.67 \mathrm{a}-\mathrm{c}$ & $6.85 b-d$ & $2.90 \mathrm{c}, \mathrm{d}$ \\
\hline 8 & $4.75 \mathrm{~d}, \mathrm{e}$ & $3.37 e, f$ & $7.45 a-c$ & $7.95 a-c$ & $8.77 \mathrm{a}, \mathrm{b}$ & $3.47 \mathrm{e}, \mathrm{f}$ & $8.12 \mathrm{a}-\mathrm{d}$ & $7.00 \mathrm{a}-\mathrm{c}$ & $7.87 \mathrm{a}, \mathrm{b}$ & $2.40 \mathrm{~b}, \mathrm{c}$ \\
\hline 9 & $4.37 \mathrm{c}-\mathrm{e}$ & $3.00 e, f$ & $7.90 a, b$ & $7.87 \mathrm{a}-\mathrm{c}$ & $8.65 a, b$ & $3.30 \mathrm{e}, \mathrm{f}$ & $8.42 a, b$ & $7.30 a, b$ & $7.30 \mathrm{a}-\mathrm{c}$ & $2.25 \mathrm{a}-\mathrm{c}$ \\
\hline 10 & $4.15 \mathrm{c}, \mathrm{d}$ & $7.90 \mathrm{a}$ & $4.00 \mathrm{~g}$ & $3.72 \mathrm{e}$ & $5.57 \mathrm{c}$ & $8.10 \mathrm{a}$ & $4.05 \mathrm{~h}$ & $3.35 d$ & $4.17 \mathrm{~g}$ & $3.45 d$ \\
\hline 11 & $1.75 \mathrm{a}$ & $4.05 \mathrm{~d}, \mathrm{e}$ & $6.40 \mathrm{c}-\mathrm{e}$ & $7.75 \mathrm{a}-\mathrm{c}$ & $9.00 \mathrm{a}$ & $4.80 \mathrm{c}, \mathrm{d}$ & $7.77 \mathrm{~b}-\mathrm{e}$ & $6.70 \mathrm{a}-\mathrm{c}$ & $5.75 \mathrm{~d}-\mathrm{f}$ & $1.55 \mathrm{a}, \mathrm{b}$ \\
\hline 12 & $2.22 \mathrm{a}, \mathrm{b}$ & $4.75 \mathrm{c}, \mathrm{d}$ & $4.80 \mathrm{f}, \mathrm{g}$ & $5.77 \mathrm{~d}$ & $8.35 a, b$ & $5.35 \mathrm{~b}, \mathrm{c}$ & $6.92 \mathrm{e}, \mathrm{f}$ & $6.72 \mathrm{a}-\mathrm{c}$ & $4.67 \mathrm{f}, \mathrm{g}$ & $2.27 \mathrm{a}-\mathrm{c}$ \\
\hline 13 & $1.60 \mathrm{a}$ & $5.32 \mathrm{~b}, \mathrm{c}$ & $4.97 \mathrm{f}, \mathrm{g}$ & $5.55 \mathrm{~d}$ & $9.00 \mathrm{a}$ & $5.40 \mathrm{~b}, \mathrm{c}$ & $5.92 \mathrm{~g}$ & $5.65 c$ & $5.22 \mathrm{e}-\mathrm{g}$ & $1.37 \mathrm{a}$ \\
\hline LSD (95\%) & 1.14 & 1.23 & 1.28 & 1.01 & 0.86 & 1.02 & 0.92 & 1.53 & 1.27 & 0.97 \\
\hline
\end{tabular}

Different letters in the same column indicate significant differences $P<0.05$.

LSD, least significant difference.

${ }^{*}$ Mashed potatoes made without blanching

**Mashed potatoes made without blanching and with added starch.

Values are given as mean score values of ten determinations. 
Table 5 Sensory attributes perceived during the final and residual phases of mastication and overall acceptability for the fresh and frozen/thawed mashed potatoes with the different blanching combinations, and controls

\begin{tabular}{|c|c|c|c|c|}
\hline Sensory attributes & Perceived during th & final and residu & iases of mastication & Overall \\
\hline Design point & Ease of swallowing & Palate coating & Fibrousness & acceptability \\
\hline Fresh mashed potatoes & & & & \\
\hline Fresh Control1* & $8.77 \mathrm{a}$ & $2.42 a-d$ & $1.32 \mathrm{a}$ & $9.00 \mathrm{a}$ \\
\hline Fresh control2** & $8.60 a, b$ & $2.05 a-c$ & $1.35 a, b$ & $8.32 a, b$ \\
\hline 1 & $4.12 \mathrm{e}$ & $3.05 d$ & $2.15 b-d$ & $3.47 \mathrm{~h}$ \\
\hline 2 & $7.85 \mathrm{a}-\mathrm{c}$ & $2.00 a, b$ & $1.90 \mathrm{a}-\mathrm{d}$ & $7.35 \mathrm{c}-\mathrm{e}$ \\
\hline 3 & $7.22 \mathrm{c}, \mathrm{d}$ & $5.47 \mathrm{e}$ & $3.12 \mathrm{e}$ & $4.45 \mathrm{~g}$ \\
\hline 4 & $8.35 a, b$ & $2.80 \mathrm{~b}-\mathrm{d}$ & $2.25 \mathrm{c}, \mathrm{d}$ & $7.37 \mathrm{c}-\mathrm{e}$ \\
\hline 5 & $8.20 a, b$ & $2.65 a-d$ & $2.40 \mathrm{~d}, \mathrm{e}$ & $6.95 e, f$ \\
\hline 6 & $8.25 a, b$ & $2.52 a-d$ & $2.27 \mathrm{c}, \mathrm{d}$ & $7.25 \mathrm{~d}, \mathrm{e}$ \\
\hline 7 & $8.42 a, b$ & $2.75 a-d$ & $2.60 \mathrm{~d}, \mathrm{e}$ & $7.47 \mathrm{~b}-\mathrm{e}$ \\
\hline 8 & $8.29 a, b$ & $2.64 a-d$ & $2.42 \mathrm{~d}, \mathrm{e}$ & $7.22 \mathrm{~d}, \mathrm{e}$ \\
\hline 9 & $8.24 \mathrm{a}, \mathrm{b}$ & $2.64 \mathrm{a}-\mathrm{d}$ & $2.41 \mathrm{~d}, \mathrm{e}$ & $7.35 \mathrm{c}-\mathrm{e}$ \\
\hline 10 & $6.70 \mathrm{~d}$ & $4.90 \mathrm{e}$ & $4.15 f$ & $4.27 \mathrm{~g}, \mathrm{~h}$ \\
\hline 11 & $8.62 \mathrm{a}, \mathrm{b}$ & $1.90 \mathrm{a}$ & $1.40 \mathrm{a}, \mathrm{b}$ & $8.25 a-c$ \\
\hline 12 & $7.72 \mathrm{~b}, \mathrm{c}$ & $2.87 \mathrm{c}, \mathrm{d}$ & $2.10 a-d$ & $6.10 \mathrm{f}$ \\
\hline 13 & $8.20 \mathrm{a}, \mathrm{b}$ & $1.90 \mathrm{a}$ & $1.52 \mathrm{a}-\mathrm{c}$ & $7.97 b-d$ \\
\hline LSD (95\%) & 0.94 & 0.87 & 0.81 & 0.92 \\
\hline $\begin{array}{l}\text { Frozen/thawed mashed } \\
\text { potatoes }\end{array}$ & & & & \\
\hline Frozen/thawed control1* & $9.00 \mathrm{a}$ & $1.65 \mathrm{a}$ & $1.37 \mathrm{a}$ & $8.95 \mathrm{a}$ \\
\hline Frozen/thawed control2** & $8.02 a-d$ & $2.32 \mathrm{a}$ & $2.15 \mathrm{~b}$ & $7.50 \mathrm{c}-\mathrm{e}$ \\
\hline 1 & $8.00 \mathrm{a}-\mathrm{d}$ & $2.20 \mathrm{a}$ & $1.97 \mathrm{a}, \mathrm{b}$ & $7.25 \mathrm{c}-\mathrm{e}$ \\
\hline 2 & $8.15 a-c$ & 4.97 b, c & $2.00 \mathrm{a}, \mathrm{b}$ & $7.02 d-f$ \\
\hline 3 & $4.70 \mathrm{f}$ & $6.22 \mathrm{~d}, \mathrm{e}$ & $2.97 \mathrm{c}$ & $4.32 \mathrm{~g}$ \\
\hline 4 & $7.92 \mathrm{a}-\mathrm{d}$ & $4.40 \mathrm{~b}$ & $2.10 a, b$ & $6.77 \mathrm{e}, \mathrm{f}$ \\
\hline 5 & $6.75 \mathrm{~d}, \mathrm{e}$ & $5.30 \mathrm{~b}-\mathrm{d}$ & $2.00 \mathrm{a}, \mathrm{b}$ & $7.50 \mathrm{c}-\mathrm{e}$ \\
\hline 6 & $8.37 a, b$ & $6.85 \mathrm{e}$ & $1.90 a, b$ & $8.00 \mathrm{~b}, \mathrm{c}$ \\
\hline 7 & $6.97 \mathrm{c}-\mathrm{e}$ & $4.82 \mathrm{~b}, \mathrm{c}$ & $1.80 \mathrm{a}, \mathrm{b}$ & $8.12 \mathrm{a}-\mathrm{c}$ \\
\hline 8 & $7.35 b-d$ & $5.67 \mathrm{c}-\mathrm{e}$ & $1.90 \mathrm{a}, \mathrm{b}$ & $7.87 b-d$ \\
\hline 9 & $7.86 a-d$ & $5.25 b-d$ & $1.95 a, b$ & $8.00 b, c$ \\
\hline 10 & 6.02 e & $4.65 b, c$ & $3.15 c$ & $3.37 \mathrm{~h}$ \\
\hline 11 & $8.77 \mathrm{a}$ & $2.02 \mathrm{a}$ & $1.37 \mathrm{a}$ & $8.62 \mathrm{a}, \mathrm{b}$ \\
\hline 12 & 7.35 b-d & $2.42 \mathrm{a}$ & $2.05 a, b$ & $6.32 \mathrm{f}$ \\
\hline 13 & $8.72 \mathrm{a}$ & $1.90 \mathrm{a}$ & $1.37 \mathrm{a}$ & $8.62 \mathrm{a}, \mathrm{b}$ \\
\hline LSD (95\%) & 1.32 & 1.19 & 0.74 & 0.91 \\
\hline
\end{tabular}

Different letters in the same column indicate significant differences $P<0.05$.

LSD, least significant difference.

*Mashed potatoes made without blanching.

${ }^{* *}$ Mashed potatoes made without blanching and with added starch.

Values are given as mean score values of ten determinations. 
Table 6 Regression coefficients, coefficient of determination $\left(R^{2}\right)$ and analysis of variance of the quadratic models for colour, TPA, firmness, oscillatory parameters and overall acceptability of fresh and frozen/thawed mashed potatoes at the design response surface

\begin{tabular}{|c|c|c|c|c|c|c|c|c|c|c|c|c|}
\hline Coefficient & $\begin{array}{l}\mathrm{L}^{*} / \mathbf{b}^{*} \\
\text { ratio }\end{array}$ & $\begin{array}{l}\text { Hardness } \\
\text { (N) }\end{array}$ & Cohesiveness & $\begin{array}{l}\text { Gumminess } \\
\text { (N) }\end{array}$ & $\begin{array}{l}\text { Area } \\
\text { (N s) }\end{array}$ & $\begin{array}{l}\text { Area/disp vol } \\
\left(\mathrm{N} \mathrm{s} \mathrm{mm}^{-3}\right)\end{array}$ & $\begin{array}{l}\text { Average } \\
\text { force (N) }\end{array}$ & $\begin{array}{l}\text { Complex } \\
\text { modulus } \\
\mathrm{G}^{*}(\mathrm{~Pa})\end{array}$ & $\begin{array}{l}\text { Storage } \\
\text { modulus } \\
\text { G' }(\mathrm{Pa})\end{array}$ & $\begin{array}{l}\text { Loss } \\
\text { modulus } \\
\text { G" }(\mathrm{Pa})\end{array}$ & $\begin{array}{l}\text { Complex } \\
\text { viscosity } \\
\eta^{\star}(\mathrm{Pa} \mathrm{s})\end{array}$ & $\begin{array}{l}\text { Overall } \\
\text { accept- } \\
\text { ability }\end{array}$ \\
\hline \multicolumn{13}{|c|}{ Fresh mashed potatoes } \\
\hline$b_{0}$ & 8.816 & 1.238 & - & 1.179 & 2.275 & $3.128 \mathrm{E}-4$ & 0.295 & 4929.490 & 4825.320 & 1000.110 & 4654.100 & 7.248 \\
\hline$b_{1}$ & $-0.179^{*}$ & $0.208^{\star \star}$ & - & $0.231^{\star \star *}$ & $0.265^{*}$ & $3.519 \mathrm{E}-5^{*}$ & $0.034^{*}$ & $1173.380^{\star * *}$ & $1169.320^{\star \star *}$ & $165.870^{\star \star \star}$ & $1109.850^{\star \star *}$ & $1.114^{* \star \star}$ \\
\hline$b_{2}$ & $0.169^{\star}$ & 0.022 & - & $5.834 \mathrm{E}-3$ & 0.012 & $1.419 \mathrm{E}-6$ & 1.669E-3 & -381.542 & -373.715 & $-81.085^{\star \star *}$ & -358.378 & $-1.180^{\star * *}$ \\
\hline$b_{11}$ & $-0.863^{\star * *}$ & $-0.136^{*}$ & - & $-0.079^{*}$ & $-0.294^{*}$ & $-4.434 \mathrm{E}-5^{\star}$ & $-0.038^{*}$ & $-722.718^{\star *}$ & $-722.806^{* *}$ & $-92.137^{\star * *}$ & $-684.755^{\star *}$ & $-0.572^{* *}$ \\
\hline$b_{22}$ & -0.090 & $-0.133^{\star}$ & - & $-0.098^{\star *}$ & -0.201 & $-3.159 \mathrm{E}-5$ & -0.026 & $-870.129^{\star *}$ & $-864.612^{* *}$ & $-119.43^{\star \star \star}$ & $-820.429^{* \star}$ & $-0.522^{\star *}$ \\
\hline$b_{12}$ & $-0.447^{\star *}$ & $-7.500 \mathrm{E}-4$ & - & 0.033 & -0.089 & $-1.200 \mathrm{E}-5$ & -0.011 & 128.625 & 127.392 & 17.664 & 119.034 & 0.187 \\
\hline$R^{2}$ & 0.840 & 0.798 & - & 0.838 & 0.745 & 0.755 & 0.744 & 0.799 & 0.800 & 0.757 & 0.801 & 0.886 \\
\hline F-Ratio & 7.348 & 5.528 & - & 7.231 & 4.086 & 4.321 & 4.065 & 5.575 & 5.591 & 4.351 & 5.644 & 10.887 \\
\hline$P$-value & 0.010 & 0.022 & - & 0.011 & 0.047 & 0.041 & 0.047 & 0.022 & 0.022 & 0.040 & 0.021 & 0.003 \\
\hline Lack of fit & $0.040^{* *}$ & 0.374 & - & 0.121 & 0.730 & 0.762 & 0.736 & 0.137 & 0.144 & 0.138 & 0.135 & $0.004^{* *}$ \\
\hline \multicolumn{13}{|c|}{ Frozen/thawed mashed potatoes } \\
\hline$b_{0}$ & 8.136 & - & 1.005 & - & - & - & - & 4266.930 & 4191.420 & 801.413 & 4019.010 & 7.898 \\
\hline$b_{1}$ & $-0.152^{*}$ & - & $-0.065^{\star \star \star}$ & - & - & - & - & $728.506^{* \star \star}$ & $722.801^{\star \star \star *}$ & $102.449^{\star *}$ & $689.230^{* \star *}$ & $0.693^{\star *}$ \\
\hline$b_{2}$ & $0.230^{* *}$ & - & $-9.263 \mathrm{E}-3$ & - & - & - & - & $-291.704^{\star}$ & $-288.344^{*}$ & -48.424 & $-272.275^{\star}$ & $-1.226^{* * *}$ \\
\hline$b_{11}$ & $-0.541^{* * *}$ & - & $0.018^{*}$ & - & - & - & - & $-644.405^{\star * *}$ & $-637.020^{* * *}$ & $-104.478^{* *}$ & $-604.798^{* * *}$ & 0.036 \\
\hline$b_{22}$ & 0.016 & - & $0.052^{* \star *}$ & - & - & - & - & $-633.032^{* * *}$ & $-625.703^{* * *}$ & $-102.069^{* *}$ & $-594.040^{* * *}$ & $-1.397^{\star \star \star}$ \\
\hline$b_{12}$ & $-0.385^{\star \star}$ & - & $-0.037^{\star *}$ & - & - & - & - & -138.400 & -130.983 & -52.257 & -126.592 & 0.100 \\
\hline$R^{2}$ & 0.877 & - & 0.821 & - & - & - & - & 0.824 & 0.824 & 0.782 & 0.824 & 0.981 \\
\hline F-Ratio & 9.962 & - & 6.440 & - & - & - & - & 6.574 & 6.569 & 5.011 & 6.545 & 70.923 \\
\hline$P$-value & 0.004 & - & 0.015 & - & - & - & - & 0.014 & 0.014 & 0.029 & 0.014 & 0.000 \\
\hline Lack of fit & 0.144 & - & $0.033^{\text {** }}$ & - & - & - & - & 0.198 & 0.194 & 0.277 & 0.193 & 0.244 \\
\hline
\end{tabular}

Subscripts: 1 = temperature; 2 = time.

Significant level: ${ }^{\star} 0.10 ;{ }^{* \star} 0.05 ;{ }^{* \star} 0.01$. 
Table 7 Stationary point and nature of the quality parameters at the design response surface

\begin{tabular}{|c|c|c|c|c|}
\hline 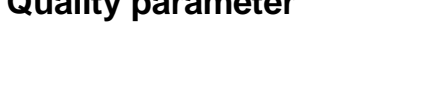 & $\left({ }^{\circ} \mathrm{C}\right)$ & (min) & $\begin{array}{l}\text { response at } \\
\text { stationary point }\end{array}$ & optimum \\
\hline \multicolumn{5}{|l|}{ Fresh mashed potatoes } \\
\hline $\mathrm{L}^{*} / \mathrm{b}^{*}$ ratio & 60.187 & 11.204 & - & - \\
\hline Gumminess (N) & 72.620 & 32.841 & - & - \\
\hline Average force $(\mathrm{N})$ & 67.300 & 29.299 & 0.303 & Maximum \\
\hline Complex viscosity, $\eta^{*}$ (Pa s) & 68.982 & 28.394 & 5124.844 & Maximum \\
\hline Overall acceptability & 69.074 & 20.166 & 8.281 & Maximum \\
\hline \multicolumn{5}{|c|}{ Frozen/thawed mashed potatoes } \\
\hline $\mathrm{L}^{*} / \mathrm{b}^{*}$ ratio & 68.002 & 27.069 & 7.805 & Maximum \\
\hline Cohesiveness & 80.330 & 41.920 & - & - \\
\hline Loss modulus, G" (Pa) & 67.760 & 28.296 & 840.875 & Maximum \\
\hline Complex viscosity, $\eta^{*}$ (Pa s) & 67.934 & 26.125 & 4256.236 & Maximum \\
\hline Overall acceptability & 21.386 & 22.490 & - & - \\
\hline
\end{tabular}


Table 8 Experimental values and values predicted by models at $70^{\circ} \mathrm{C}$ and $25 \mathrm{~min}$

\begin{tabular}{|c|c|c|c|}
\hline $\begin{array}{l}\text { Response } \\
\text { variable }\end{array}$ & $\begin{array}{l}\text { Experimental } \\
\text { value }\end{array}$ & $\begin{array}{l}\text { Predicted } \\
\text { value }\end{array}$ & $\begin{array}{l}\text { Residual } \\
\text { percentage }\end{array}$ \\
\hline \multicolumn{4}{|l|}{ Fresh mashed potatoes } \\
\hline Average force $(\mathrm{N})$ & 0.297 & 0.289 & +2.768 \\
\hline Complex viscosity, $\eta^{*}$ (Pa s) & 4899.564 & 4993.756 & -1.886 \\
\hline Overall acceptability & 8.360 & 8.155 & +2.514 \\
\hline \multicolumn{4}{|c|}{ Frozen/thawed mashed potatoes } \\
\hline $\mathrm{L}^{*} / \mathrm{b}^{*}$ ratio & 8.020 & 7.524 & +6.592 \\
\hline Loss modulus, G" (Pa) & 848.903 & 824.207 & +2.977 \\
\hline Complex viscosity, $\eta^{*}$ (Pa s) & 3958.751 & 4154.368 & -4.709 \\
\hline
\end{tabular}




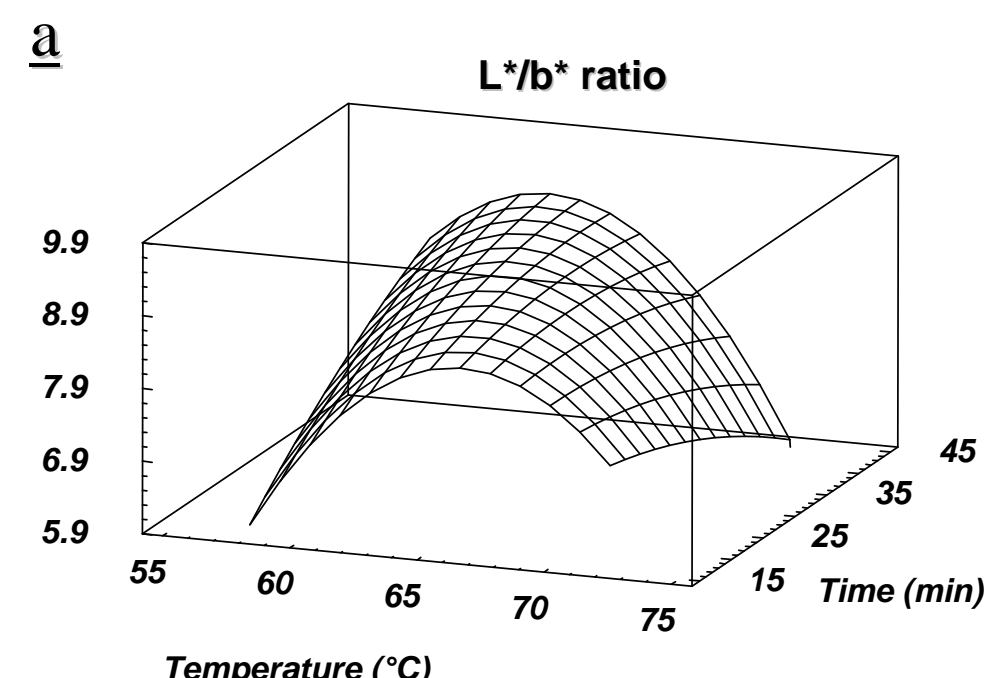

Temperature $\left({ }^{\circ} \mathrm{C}\right)$

$\underline{\mathrm{c}}$

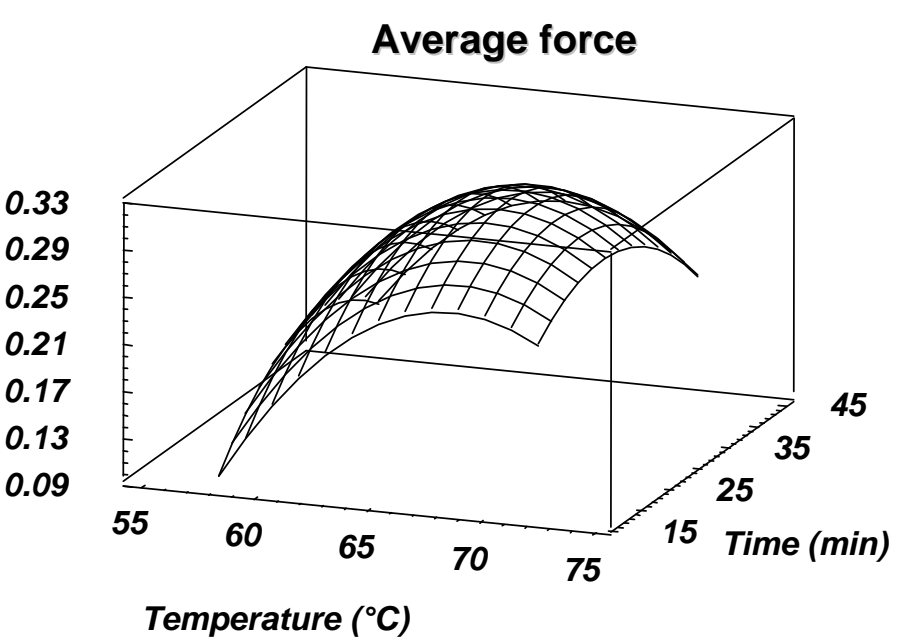

$\underline{b}$

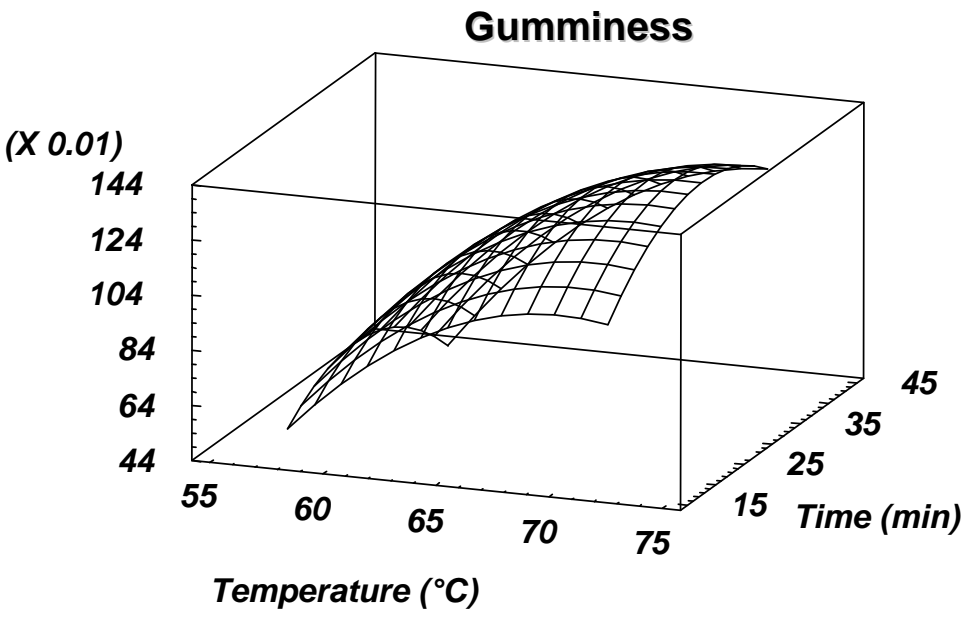

$\underline{\mathrm{d}}$

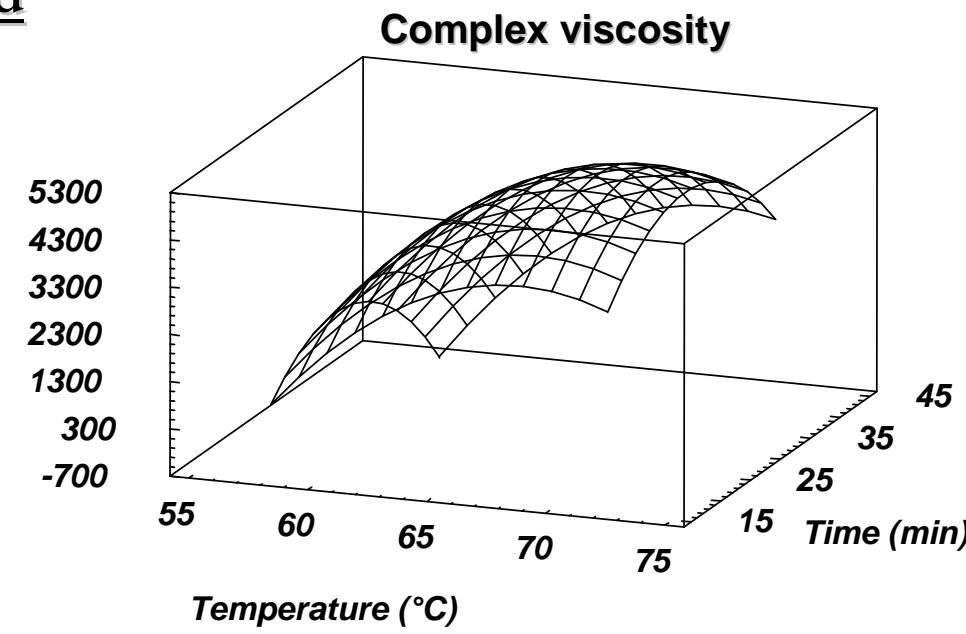

Figure 1 
$\underline{\mathrm{a}}$

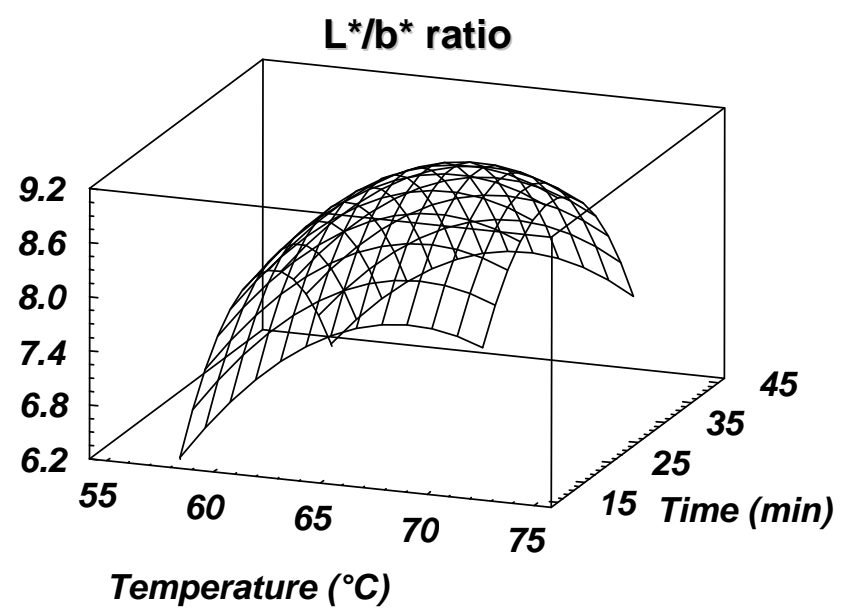

$\underline{\mathrm{c}}$

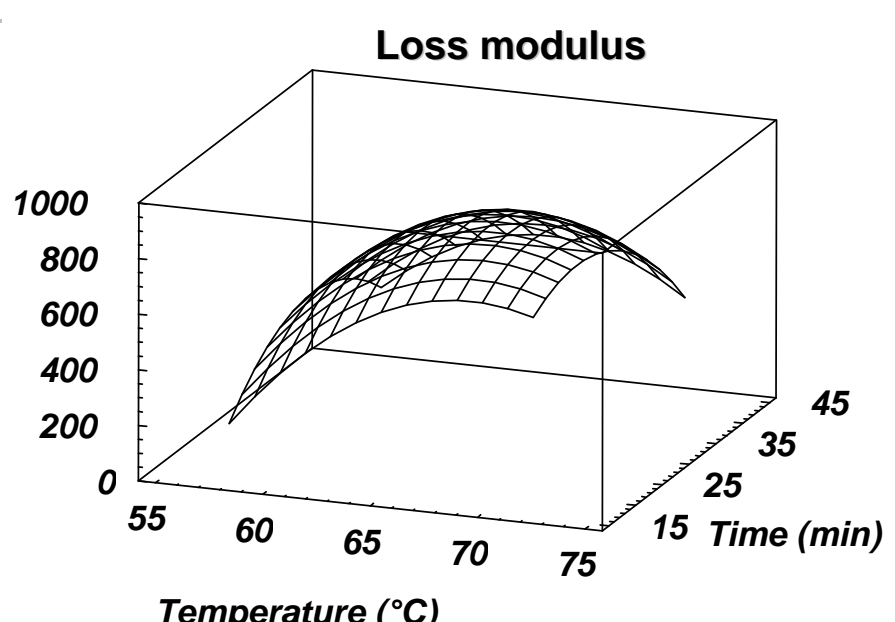

$\underline{b}$

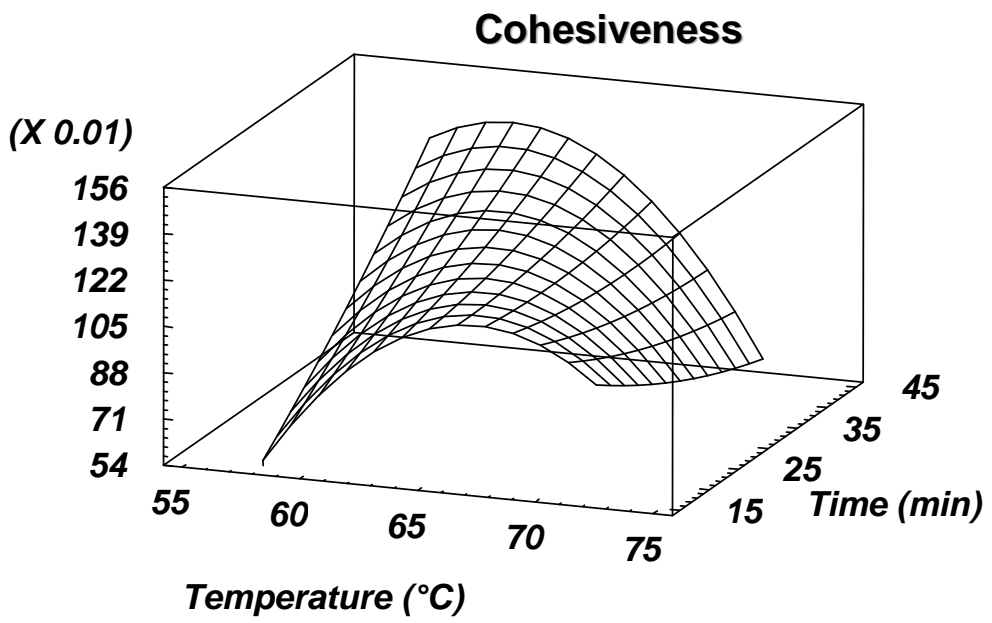

d

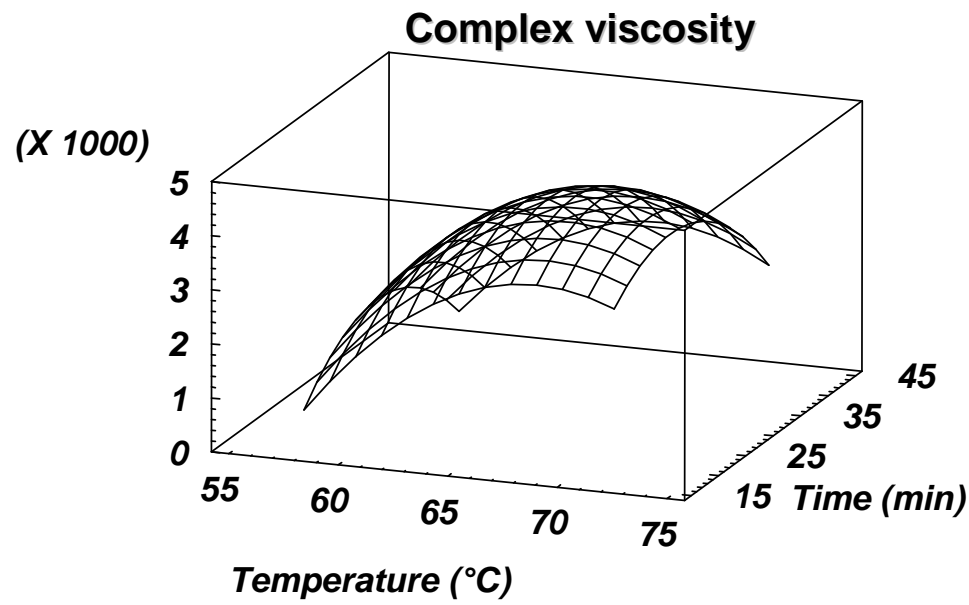

Figure 2 
$\underline{\mathrm{a}}$ Overall acceptability

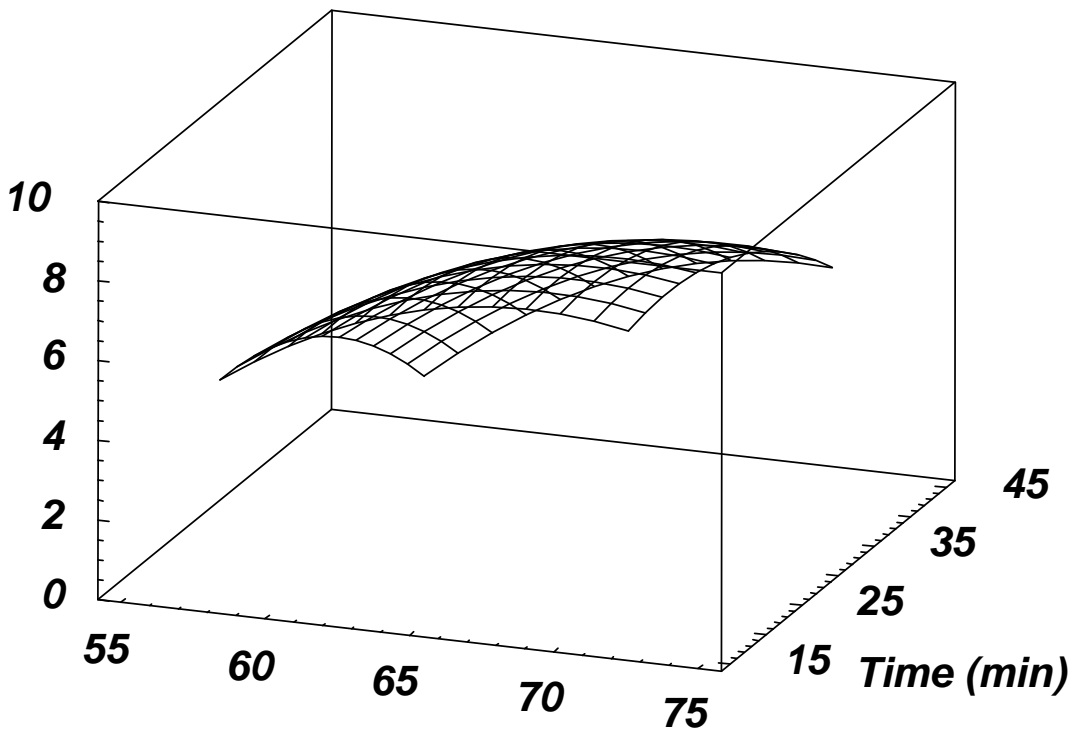

Temperature $\left({ }^{\circ} \mathrm{C}\right)$

$\underline{b}$

Overall acceptability

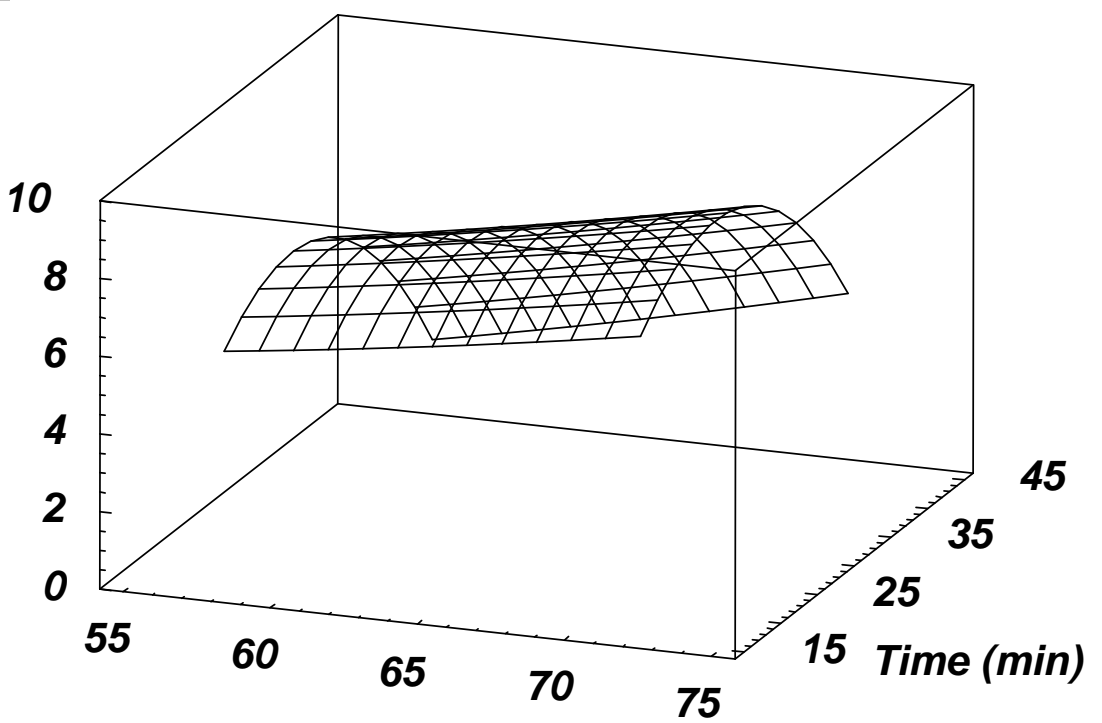

Figure 3 Temperature $\left({ }^{\circ} \mathrm{C}\right)$ 